\title{
Article \\ Cyclohexylammonium Hexaisothiocyanatonickelate(II) Dihydrate as a Single-Source Precursor for High Surface Area Nickel Oxide and Sulfide Nanocrystals
}

\author{
Mohamed F. Aly Aboud 1,2,+ $\mathbb{D}$, Abdulmalik M. BinTaleb ${ }^{3,+}$, Hamdi Ben Yahia ${ }^{4}$, Abdelhamid Albaid ${ }^{5}$, \\ Sultan Albishi ${ }^{3}$, Rasheed Arasheed ${ }^{3}$, Ibrahim Albinali ${ }^{3}$, Fahad Albaqi ${ }^{3}$ (D), Khalid Anojaidi ${ }^{3}$, Fahad Alqahtani ${ }^{6}$, \\ Asma M. Alenad ${ }^{7}$ (D), Kamal Taha ${ }^{8, *}$ and Abdulaziz Bagabas ${ }^{3, *(\mathbb{D})}$
}

check for updates

Citation: Aboud, M.F.A.; BinTaleb, A.M.; Yahia, H.B.; Albaid, A.; Albishi, S.; Arasheed, R.; Albinali, I.; Albaqi, F.; Anojaidi, K.; Alqahtani, F.; et al. Cyclohexylammonium Hexaisothiocyanatonickelate(II) Dihydrate as a Single-Source Precursor for High Surface Area Nickel Oxide and Sulfide Nanocrystals. Crystals 2022, 12, 315 . https://doi.org/10.3390/cryst12030315

Academic Editors: Assem Barakat and Alexander S. Novikov

Received: 29 December 2021 Accepted: 18 February 2022 Published: 23 February 2022

Publisher's Note: MDPI stays neutral with regard to jurisdictional claims in published maps and institutional affiliations.

Copyright: (C) 2022 by the authors. Licensee MDPI, Basel, Switzerland. This article is an open access article distributed under the terms and conditions of the Creative Commons Attribution (CC BY) license (https:// creativecommons.org/licenses/by/ $4.0 /)$.
1 Sustainable Energy Technologies Center, College of Engineering, King Saud University, P.O. Box 800, Riyadh 11421, Saudi Arabia; maboud@ksu.edu.sa

2 Mining, Metallurgical and Petroleum Engineering Department, Faculty of Engineering, Al-Azhar University, Nasr City, Cairo 11371, Egypt

3 National Petrochemical Technology Center (NPTC), Materials Science Research Institute (MSRI), King Abdulaziz City for Science and Technology (KACST), P.O. Box 6086, Riyadh 11442, Saudi Arabia; bintaleba@gmail.com (A.M.B.); s-albishi@outlook.sa (S.A.); rrisheed@kacst.edu.sa (R.A.); ialali@kacst.edu.sa (I.A.); f-albaqai@hotmail.com (F.A.); khalid.alnjaidi@gmail.com (K.A.)

4 Qatar Environment and Energy Research Institute (QEERI), Hamad Bin Khalifa University, Qatar Foundation, Doha P.O. Box 34110, Qatar; benyahia_hamdi@yahoo.fr

5 Department of Physics, Faculty of Science, University of Ha'il, P.O. Box 2440, Ha'il 81451, Saudi Arabia; albaid1979@gmail.com

6 College of Sciences and Humanities, Prince Sattam Bin Abdulaziz University, P.O. Box 710, Aflaj 11912, Saudi Arabia; fahad.alqahtani@psau.edu.sa

7 Chemistry Department, College of Science, Jouf University, Sakaka P.O. Box 2014, Saudi Arabia; amenad@ju.edu.sa

8 Department of Chemistry \& Industrial Chemistry, College of Applied and Industrial Sciences, University of Bahri, Khartoum 12217, Sudan

* Correspondence: kamaltha60@gmail.com (K.T.); abagabas@hotmail.com (A.B.)

+ First co-authors.

Abstract: Cyclohexylammonium hexaisothiocyanatonickelate(II) dihydrate, $\left(\mathrm{C}_{6} \mathrm{H}_{11} \mathrm{NH}_{3}\right)_{4}\left[\mathrm{Ni}(\mathrm{NCS})_{6}\right] \cdot 2 \mathrm{H}_{2} \mathrm{O}$, was synthesized, for the first time, by a four-step method in a yield of $95 \%$. The compound was fully characterized by elemental microanalysis, Fourier transform infrared (FTIR), ultraviolet-visible-near infrared (UV-Vis-NIR), and nuclear magnetic resonance (NMR) spectroscopy and thermogravimetry. A single crystal X-ray diffraction (SXRD) gave the monoclinic space group $P 2{ }_{1} / c$ with $a=15.8179$ (5) $\AA, b=10.6222$ (3) $\AA, c=13.8751$ (4) $\AA$, $\beta=109.362$ (1) ${ }^{\circ}$, $V=2199.45(11) \AA^{3}, Z=2(T=293 \mathrm{~K})$ for this novel hybrid organic-inorganic compound. The title compound was employed as a single-source precursor for the synthesis of mesoporous, high surface

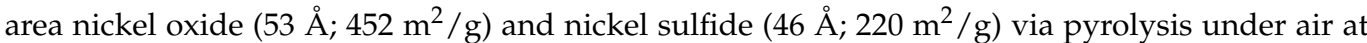
$550{ }^{\circ} \mathrm{C}$ or helium atmosphere at $500{ }^{\circ} \mathrm{C}$, respectively. X-ray powder diffraction (XRPD) demonstrated the nanocrystalline nature of both $\mathrm{NiO}$ and $\mathrm{NiS}$ with an average crystallite size of 16 and $54 \mathrm{~nm}$, respectively. Scanning electron microscope (SEM) indicated the formation of agglomerated, quasispherical particles of nickel oxide and agglomerated flake-like structures of nickel sulfide. The high surface area, porosity, and nanocrystallinity of both $\mathrm{NiO}$ and $\mathrm{NiS}$, obtained via this approach, are promising for a wide spectrum of applications.

Keywords: cyclohexylammonium; hexaisothiocyanatonickelate(II); pyrolysis; nickel oxide; nickel sulfide

\section{Introduction}

For more than 100 years, the triatomic linear thiocyanate $[\mathrm{SCN}]^{-}$or isothiocyanate $[\mathrm{NCS}]^{-}$ligand has captured the attention of many researchers due to its low toxicity and 
varied coordination modes to metal ions. It can bind to the metal center as a terminal monodentate linker via N- or S-atom, according to Pearson's hard-soft acid-base (HSAB) classification concept. Furthermore, it binds to metal cations in bridging mode through nitrogen and sulfur atoms, $\mathrm{M}-\mathrm{NCS}-\mathrm{M}[1,2]$. These different modes of coordination lead to the formation of compounds with major diversity in chemical, physical, and structural properties. Therefore, in the context of correlating thiocyanate complex structures with their properties, Christian et al. prepared manganese, cobalt, and nickel thiocyanate complexes, which exhibited cooperative magnetic phenomena. Such complexes dramatically changed their magnetic properties upon thermal decomposition [3]. In addition, manganese, iron, and nickel thiocyanate complexes with 4-ethylpyridine, as a co-ligand, were synthesized and investigated to show cooperative magnetic phenomena [4]. In another application, the $\left[\mathrm{Ni}(\mathrm{SCN})_{4}(2-\text { methylpiperazine })_{2}\right]$ complex was effective against the activities of bacteria such as E. coli, S. typhimurium, E. feacium, and C. albicans [5]. The complex of [Ni(NCS) 2 (paraphenylpyridine $)_{4}$ ] showed remarkable isomeric selectivity for ortho-xylene over meta- and para-xylene from a ternary mixture, and a similar selectivity for meta- over para-xylene from a binary mixture [6].

Hybrid organic-inorganic compounds, based on the bulky anionic complex of hexaisothiocyanatonickelate(II), $\left[\mathrm{Ni}(\mathrm{NCS})_{6}\right]^{4-}$, have also drawn considerable attention due to their promising applications [7-13], depending on the identity of the organic cation. For instance, when the organic cation was 1-butyl-3-methylimidazolium, BMIM+, the resultant compound exhibited ionic liquid nature and reversible thermochromic behavior [7]. However, when the organic cation was tetrakis(triethylammonium), the eventually produced compound was a useful precursor for the synthesis of anhydrous nickel thiocyanate [8]. The piperidinium cation resulted in a new compound, which could be used for the preparation of nickel sulfide via thermal decomposition under nitrogen [9]. Incorporation of triphenylmethylphosphonium cation in a compound with $\left[\mathrm{Ni}(\mathrm{NCS})_{6}\right]^{4-}$ produced ferroelectric, piezoelectric material, which was suitable for harvesting energy upon its integration, $15 \mathrm{wt} . \%$, in thermoplastic polyurethane [10]. On the other hand, introducing trimethylammonium gave a suitable material for a dielectric switch, tuned by frequency, as a result of phase transition [11].

On the basis of the organic cation, cyclohexylammonium is a unique building block due to its capability to form various dimensional structures, depending on the identity of its counter anion and the presence of solvent of crystallization molecules, via its hydrogen donor nature [14-37]. Another attractive feature of cyclohexylammonium is its usefulness as a soft organic template for the creation of mesopores, after its thermal decomposition, within the produced ceramic [26,38,39].

Metal sulfides have received high attention as semiconductors and for other applications. Dithiocarbamate of general formula $\left(\mathrm{R}_{2} \mathrm{CNS}_{2}{ }^{-}\right)$was extensively reported as a single-source precursor (SSP) for metal sulfides [40-44] in the form of thin films or nanoparticles $[45,46]$. Although there have been thorough investigations of several thiocyanate or isothiocyanate metal compounds, none of them has been utilized as an SSP for metal sulfides or oxides $[3,8,12,13,47-53]$. Recently, we have reported cyclohexylammonium tetraisothiocyanatocobaltate(II) as an SSP for cobalt sulfide (CoS) and tricobalt tetraoxide $\left(\mathrm{Co}_{3} \mathrm{O}_{4}\right)$ nanoparticles [26], while cyclohexylammonium hexaisothiocyanatochromate(III) sesquihydrate as an SSP for nanocrystalline chromium sulfide $\left(\mathrm{Cr}_{2} \mathrm{~S}_{3}\right)$ and chromium oxide $\left(\mathrm{Cr}_{2} \mathrm{O}_{3}\right)$ [38].

In this work, cyclohexylammonioum hexaisothiocyanatonickelate(II) dihydrate, $\left(\mathrm{C}_{6} \mathrm{H}_{11} \mathrm{NH}_{3}\right)_{4}\left[\mathrm{Ni}(\mathrm{NCS})_{6}\right] \cdot 2 \mathrm{H}_{2} \mathrm{O}$ was synthesized, characterized, and utilized as an SSP, via its thermal decomposition under two different atmospheres, for high surface area, mesoporous, nanocrystalline nickel sulfide (NiS) and nickel oxide (NiO).

\section{Material and Methods}

Nickel nitrate hexahydrate $\left[\mathrm{Ni}\left(\mathrm{NO}_{3}\right)_{2} \cdot 6 \mathrm{H}_{2} \mathrm{O}\right.$; purum p.a.; crystallized; $\geq 98.0 \%$, SigmaAldrich, St. Louis, MI, USA], sodium thiocyanate (NaNCS; pure; 99\%; Riedel-de Haën 
AG, Seelze, Germany), cyclohexylamine [C6H11NH2; >99.0\%(GC); TCI], hydrochloric acid $(\mathrm{HCl} ; 37 \%$; certified AR for analysis; Fisher Chemical; Fisher Scientific, Waltham, MA, USA), and ethanol absolute (EtOH; GRG, Shibuya-ku, Japan; 99.9\%; PETROCHEM) were commercially available and were used without further purification.

Synthesis of $\left(\mathrm{C}_{6} \mathrm{H}_{11} \mathrm{NH}_{3} \mathrm{Cl}\right)$ : cyclohexylammonium chloride $\left(\mathrm{C}_{6} \mathrm{H}_{11} \mathrm{NH}_{3} \mathrm{Cl}\right)$ was prepared by the direct reaction of $110 \mathrm{mmol}$ of cyclohexylamine $(12.6 \mathrm{~mL})$, dissolved in $100 \mathrm{~mL}$ of water of $110 \mathrm{mmol}$ of hydrochloric acid $(\sim 9.2 \mathrm{~mL}$ of $37 \% \mathrm{HCl})$, diluted to $100 \mathrm{~mL}$, in an ice bath, was added gradually to the cyclohexylamine solution over a period of $30 \mathrm{~min}$. Colorless crystals of cyclohexylammonium chloride (14.9 g; quantitative yield) were obtained by evaporation of water solvent at room temperature.

Synthesis of $\left(\mathrm{C}_{6} \mathrm{H}_{11} \mathrm{NH}_{3} \mathbf{N C S}\right)$ : cyclohexylammonium thiocyanate $\left(\mathrm{C}_{6} \mathrm{H}_{11} \mathrm{NH}_{3} \mathrm{NCS}\right)$ was obtained from the metathesis reaction between cyclohexylammonium chloride and sodium thiocyanate in ethanol medium, as it was described in the literature $[26,34,38]$. The synthesis of $\mathrm{C}_{6} \mathrm{H}_{11} \mathrm{NH}_{3} \mathrm{NCS}$ was the second step in our approach. In a typical reaction, a solution of sodium thiocyanate NaSCN (8.107 g; $100 \mathrm{mmol})$ in $\mathrm{EtOH}(350 \mathrm{~mL})$ was added to a solution of cyclohexylammonium chloride $\left(\mathrm{C}_{6} \mathrm{H}_{11} \mathrm{NH}_{3} \mathrm{Cl} ; 13.563 \mathrm{~g} ; 100 \mathrm{mmol}\right)$ in EtOH $(350 \mathrm{~mL})$ with stirring at room temperature. Afterward, a precipitate of $\mathrm{NaCl}$ byproduct was filtered off, while the filtrate was left for slow evaporation at room temperature to obtain the desired product of $\mathrm{C}_{6} \mathrm{H}_{11} \mathrm{NH}_{3} \mathrm{NCS}$, which was purified by recrystallization with a yield of $99 \%$.

Synthesis of $\mathrm{Ni}(\mathrm{NCS})_{2}$ : A solution of sodium thiocyanate $(1.6214 \mathrm{~g} ; 20 \mathrm{mmol})$ in EtOH $(50 \mathrm{~mL})$ was poured, with stirring, into a solution of $\mathrm{Ni}\left(\mathrm{NO}_{3}\right)_{2} \cdot 6 \mathrm{H}_{2} \mathrm{O}(2.908 \mathrm{~g} ; 10 \mathrm{mmol})$ in $\mathrm{EtOH}(50 \mathrm{~mL})$ at room temperature. Then, a clear, light green ethanolic solution was obtained after the filtration of the precipitated sodium nitrate $\left(\mathrm{NaNO}_{3}\right)$ with a yield of $1.68 \mathrm{~g}(99 \%)$.

Synthesis of $\left(\mathrm{C}_{6} \mathrm{H}_{11} \mathrm{NH}_{3}\right)_{4}\left[\mathrm{Ni}(\mathrm{NCS})_{6}\right] \cdot \mathbf{2} \mathrm{H}_{2} \mathrm{O}$ : cyclohexylammonium hexaisothiocyanatonickelate(II) dihydrate was prepared by a ligand addition reaction, where $40 \mathrm{mmol}$ (6.3304 g) of $\mathrm{C}_{6} \mathrm{H}_{11} \mathrm{NH}_{3} \mathrm{NCS}$ crystals was added to $\left[\mathrm{Ni}(\mathrm{NCS})_{2}\right]_{(\mathrm{EtOH})}$ under continuous magnetic stirring until the completion of the reaction, as it was indicated by the complete dissolution of $\mathrm{C}_{6} \mathrm{H}_{11} \mathrm{NH}_{3} \mathrm{NCS}$. Green crystals of the target compound were obtained by the roomtemperature evaporation of $\mathrm{EtOH}$ over a period of a week. The crystals were purified by dissolving them in the minimum amount of $\mathrm{EtOH}$, followed by filtration of the undissolved white crystals of $\mathrm{NaNO}_{3}$ (proven by XRD analysis), and then by the room-temperature evaporation of EtOH to give $8.0174 \mathrm{~g}$ of the target compound crystals (95\% yield). The overall yield of the multistep reactions of the new target compound was $93 \%$. The synthesis procedure is illustrated in Scheme 1.

(i) $4 \mathrm{C}_{6} \mathrm{H}_{11} \mathrm{NH}_{2}+4 \mathrm{HCl} \underset{0^{\circ} \mathrm{C}}{\stackrel{\mathrm{H}_{2} \mathrm{O}}{\longrightarrow}} 4 \mathrm{C}_{6} \mathrm{H}_{11} \mathrm{NH}_{3} \mathrm{Cl}$

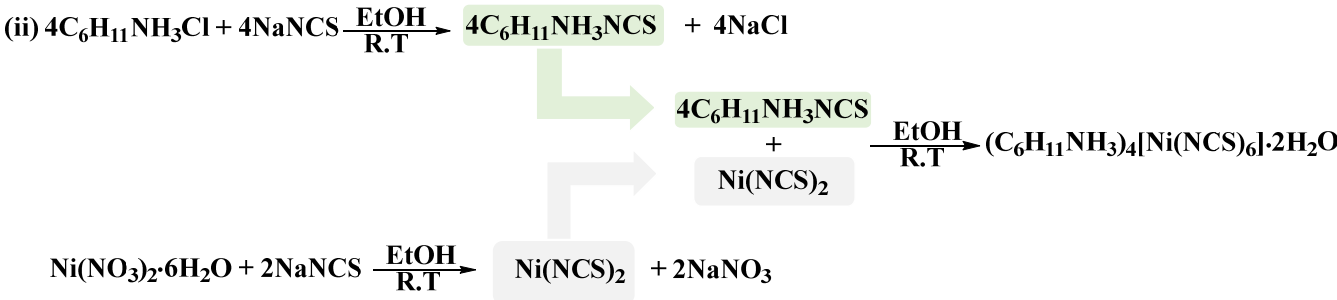

Scheme 1. Schematic diagram for the synthesis of $\left(\mathrm{C}_{6} \mathrm{H}_{11} \mathrm{NH}_{3}\right)_{4}\left[\mathrm{Ni}(\mathrm{NCS})_{6}\right] \cdot 2 \mathrm{H}_{2} \mathrm{O}$.

Our preparation method of $\left(\mathrm{C}_{6} \mathrm{H}_{11} \mathrm{NH}_{3}\right)_{4}\left[\mathrm{Ni}(\mathrm{NCS})_{6}\right] \cdot 2 \mathrm{H}_{2} \mathrm{O}$ is straightforward and cost-effective because it is performed at room temperature. On the other hand, thermal methods are required for the preparation of the reported hybrid organic-inorganic compounds of $\left[\mathrm{Ni}(\mathrm{NCS})_{6}\right]^{4-}[7,9]$. Moreover, our method gave excellent yield, while the synthesis procedures of $\left[\left(\mathrm{C}_{2} \mathrm{H}_{5}\right)_{4} \mathrm{~N}\right]_{4}\left[\mathrm{Ni}(\mathrm{NCS})_{6}\right][18],\left[\left(\mathrm{C}_{6} \mathrm{H}_{5}\right)_{3} \mathrm{PMe}\right]_{4}\left[\mathrm{Ni}(\mathrm{NCS})_{6}\right][10]$, 
$\left[\left(\mathrm{H}_{3} \mathrm{C}\right)_{3} \mathrm{NH}\right]_{4}\left[\mathrm{Ni}(\mathrm{NCS})_{6}\right][11]$, and $(\mathrm{BMIM})_{4}\left[\mathrm{Ni}(\mathrm{NCS})_{6}\right]$ [7] resulted in yields of $36 \%, 55 \%$, $80 \%$, and $93 \%$, respectively.

\subsection{Elemental Microanalysis}

A PerkinElmer Series II CHNS/O analyzer was used to quantify carbon, hydrogen, nitrogen, sulfur, and oxygen in the novel organic-inorganic hybrid compound. On the other hand, an Agilent 700 series inductively-coupled plasma-optical emission (ICP-OE) spectroscopy was used to quantify the nickel content.

\subsection{Fourier Transform Infrared (FTIR) Spectrophotometry Analysis}

A PerkinElmer Spectrum GX was used for FTIR analysis. All samples were ground to a fine powder before they were mixed with 10-15 weight times of FTIR-grade potassium bromide (KBr). The diffuse reflectance infrared Fourier transform spectroscopy (DRIFTS) analysis was recorded in the range of $400-4000 \mathrm{~cm}^{-1}$.

\subsection{UV-Visible-Near Infrared Absorbance Spectrophotometry (UV-Vis-NIR)}

A Perkin Elmer Lambda 950 UV/Vis/NIR spectrophotometer was used to record the liquid-state UV-Vis-NIR absorbance spectrum for the new compound in the range of $350-1100 \mathrm{~nm}$.

\subsection{Nuclear Magnetic Resonance (NMR) Spectroscopic Analyses}

Proton and carbon NMR analyses were carried out on a Joel $600 \mathrm{MHz}$ by using deuterated methanol.

\subsection{Single Crystal X-ray Diffraction Measurements}

The data collections were carried out at $293 \mathrm{~K}$ and $120 \mathrm{~K}$, on a Bruker D8 Venture diffractometer by using $\mathrm{MoK}_{\alpha}$ radiation. Single crystals of $\left(\mathrm{C}_{6} \mathrm{H}_{11} \mathrm{NH}_{3}\right)_{4}\left[\mathrm{Ni}(\mathrm{NCS})_{6}\right] \cdot 2 \mathrm{H}_{2} \mathrm{O}$, suitable for X-ray diffraction, were selected on the basis of the size and the sharpness of the diffraction spots. Data processing and all refinements were performed with the Jana 2006 program package [54]. A multi-scan-type absorption correction was applied by using SADABS in Apex3 software package Bruker 2012 and the crystal shape was determined with the video microscope.

\subsection{Thermal Gravimetric Analysis (TGA)}

The Q50 thermal gravimetric analyzer (TGA) was used to study the thermal decomposition of the new compound under two different atmospheres: air and helium. Both TGA analyses were carried out at a $5.0^{\circ} \mathrm{C} / \mathrm{min}$ ramping rate from room temperature to $800^{\circ} \mathrm{C}$.

\section{Results and Discussion}

\subsection{Elemental Analysis}

Satisfactory elemental analyses were obtained for all the elements present. Calculated and found values are compiled in Table 1. Furthermore, crystal structure determination by single-crystal X-ray diffraction (SCXRD) resulted in the same molecular formula.

Table 1. Elemental microanalysis for $\left(\mathrm{C}_{6} \mathrm{H}_{11} \mathrm{NH}_{3}\right)_{4}\left[\mathrm{Ni}(\mathrm{NCS})_{6}\right] \cdot 2 \mathrm{H}_{2} \mathrm{O}$.

\begin{tabular}{ccc}
\hline Element & Theoretical (wt/wt\%) & Experimental (wt/wt $\%)$ \\
\hline C & 42.70 & 42.57 \\
H & 7.17 & 7.12 \\
$\mathrm{~N}$ & 16.60 & 16.58 \\
$\mathrm{~S}$ & 22.80 & 22.65 \\
$\mathrm{O}$ & 3.79 & 3.68 \\
$\mathrm{Ni}$ & 6.95 & 6.86 \\
\hline
\end{tabular}




\subsection{FTIR Analysis}

The FTIR spectrum in Figure 1 shows different vibrational frequencies for $v_{\mathrm{O}-\mathrm{H}}$, $v_{\mathrm{N}-\mathrm{H}}, v_{\mathrm{C}-\mathrm{H}}, v_{\mathrm{C}=\mathrm{N}}, v_{\mathrm{C}-\mathrm{N}}$, and $v_{\mathrm{C}=\mathrm{S}}$. These frequencies represent the cation, anion, and crystallization water molecules within the crystal of the synthesized novel, hybrid organicinorganic compound. The spectrum displays two broad, medium intensity bands at 3555 and $3438 \mathrm{~cm}^{-1}$, which might correspond to the stretching of $v_{\mathrm{O}-\mathrm{H}}$ for the crystallization water molecules. The broadness of these peaks indicates their participation in forming intermolecular hydrogen bonds. This assumption regarding hydrogen bonds was confirmed by a careful analysis of the crystal structure, which was determined by SCXRD. The strong sharp band at $1585 \mathrm{~cm}^{-1}$ could be ascribed to the water bending mode. The strong, broad peaks in the range of $3150-3000 \mathrm{~cm}^{-1}$ might be attributed to the asymmetric stretching vibrations of $v_{\mathrm{N}-\mathrm{H}}$ of the cyclohexylammonium cations. This bathochromic shift in the asymmetric stretch of $v_{\mathrm{N}-\mathrm{H}}$ could be owing to the positively charged nitrogen atom and to the hydrogen bonds with the other moieties in the compound, as it was verified by SCXRD. We could observe the $\mathrm{N}-\mathrm{H}$ scissoring at $1585 \mathrm{~cm}^{-1}$ (strong), wagging at 1321 and $1282 \mathrm{~cm}^{-1}$ (medium), and twisting at $919 \mathrm{~cm}^{-1}$ (medium). The peak at $2936 \mathrm{~cm}^{-1}$ would be assigned to the asymmetric stretching of $v_{\mathrm{C}-\mathrm{H}}$, while the peak at $2858 \mathrm{~cm}^{-1}$ might be assigned to the symmetric stretching of $v_{\mathrm{C}-\mathrm{H}}$ of the cyclohexylammonium [55]. The $\mathrm{C}-\mathrm{H}$ deformation could be ascribed to the bands at 1495 and $1448 \mathrm{~cm}^{-1}$, while its wagging at $1227 \mathrm{~cm}^{-1}$, its twisting at 1120 and $1065 \mathrm{~cm}^{-1}$, its bending at $869 \mathrm{~cm}^{-1}$, and its rocking at 841,792 , and $546 \mathrm{~cm}^{-1}$. The stretching vibrations of $v_{\mathrm{C}-\mathrm{N}}$ might be assigned to the bands at 1034 and $1000 \mathrm{~cm}^{-1}$, while its bending at $495 \mathrm{~cm}^{-1}$ [56-58]. The ring deformation could be observed at 1174,890 , and $790 \mathrm{~cm}^{-1}$. On the other hand, the ring breathing could be detected at $956 \mathrm{~cm}^{-1}$. The band at $2235 \mathrm{~cm}^{-1}$ might be an indication for some absorbed atmospheric $\mathrm{CO}_{2}[59,60]$. The ligand of $\mathrm{N}=\mathrm{C}=\mathrm{S}$ exhibited strong asymmetric stretching vibrations for $v_{\mathrm{N}=\mathrm{C}}$ at 2091 and $2063 \mathrm{~cm}^{-1}$ [61], which were evidence for the binding of the N-terminal of NCS ligands to Ni(II) ion center, while the splitting of the band at 2091 and $2063 \mathrm{~cm}^{-1}$, circled in Figure 1, might indicate the distortion of the octahedral structure of the anionic complex of $[\mathrm{Ni}(\mathrm{NCS}) 6]^{4-}$. On the other hand, the symmetric stretching of the NCS ligand could be observed at $921 \mathrm{~cm}^{-1}$, with weak stretching vibrations for $v_{\mathrm{C}=\mathrm{S}}$ at 774 and $786 \mathrm{~cm}^{-1}$, and bending at $475 \mathrm{~cm}^{-1}[3,62]$. These observed bands of NCS ligand, shifted towards lower wavenumbers, implied some loss of $\mathrm{CN}$ triple bond character $\left(2091 \mathrm{~cm}^{-1}\right)$ and coordination to nickel ion center via N-terminal, while the shift towards higher wavenumbers for the $\mathrm{CS}$ bond implied some gain of $\mathrm{C}=\mathrm{S}$ double bond character [63]. Thus, FTIR spectrophotometry verified the formation of the target hybrid organic-inorganic compound, which was also confirmed by UV-Vis-NIR absorbance and SCXRD.

\subsection{UV-Vis-NIR Analysis}

Figure 2 shows the UV-Vis-NIR absorbance spectrum of $\left(\mathrm{C}_{6} \mathrm{H}_{11} \mathrm{NH}_{3}\right)_{4}\left[\mathrm{Ni}(\mathrm{NCS})_{6}\right] \cdot 2 \mathrm{H}_{2} \mathrm{O}$, in methanol, at room temperature, as a function of energy and wavenumber. The spectrum exhibited three distinguished peaks at $1.22 \mathrm{eV}\left(9842.25 \mathrm{~cm}^{-1} ; v_{1}\right), 1.97 \mathrm{eV}\left(15,898.25 \mathrm{~cm}^{-1}\right.$; $\left.v_{2}\right)$, and $3.17 \mathrm{eV}\left(25,575.45 \mathrm{~cm}^{-1} ; v_{3}\right)$, where all these peaks were assigned to spin-allowed transitions. The $v_{1}$ peak corresponds to the ${ }^{3} \mathrm{~A}_{2 g}(\mathrm{~F}) \rightarrow{ }^{3} \mathrm{~T}_{2 g}(\mathrm{~F})$ transition, the $v_{2}$ to the ${ }^{3} \mathrm{~A}_{2 \mathrm{~g}}(\mathrm{~F}) \rightarrow{ }^{3} \mathrm{~T}_{1 \mathrm{~g}}(\mathrm{~F})$ transition, and the $v_{3}$ the ${ }^{3} \mathrm{~A}_{2 \mathrm{~g}}(\mathrm{~F}) \rightarrow{ }^{3} \mathrm{~T}_{1 \mathrm{~g}}(\mathrm{P})$ transition, as per the Tanabe-Sugano diagram for octahedral $\mathrm{d}^{8}$ metal ion center [12,13]. With considering the significance of the interactions between metal and ligand and the separating energy of $\sim 1.0 \mathrm{eV}$ between each two successive absorption bands, we could assign the $v_{3}$ transition to ligand-metal charge transfer (LMCT) because it was the strongest in terms of energy and intensity, ascribe the $v_{2}$ transition to ligand field (d-d) band, and attribute the $v_{1}$ transition to both of d-d and LMCT, where part of LMCT is symmetrically banned for the perfectly octahedral hexaisothiocyanatonickelate(II) and feebly permitted in the real distorted structure of this complex, and hence, $v_{1}$ transition was observed stronger and more intense than $v_{2}$ transition. Furthermore, the ratio between the positions of two successive peaks was $\sim 1.61$, indicating the formation of octahedral $\mathrm{Ni}$ (II) complex without 
tetragonal distortion [13]. All these observations, inferred from the UV-Vis-NIR spectrum, confirmed the formation of the anionic complex of $\left[\mathrm{Ni}(\mathrm{NCS})_{6}\right]^{4-}$ and were in agreement with the above FTIR spectrum and with the crystal structure determination by SCXRD.

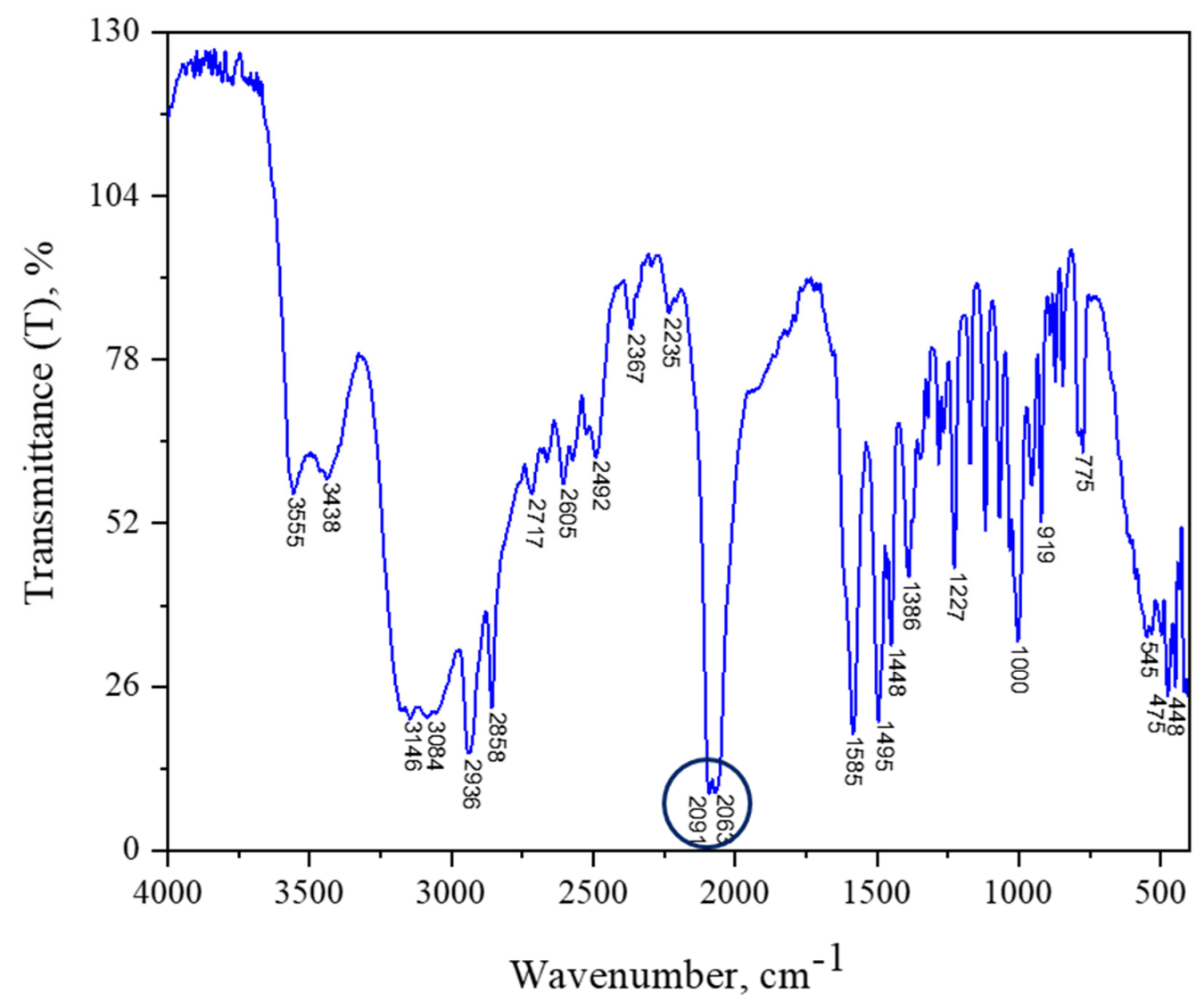

Figure 1. FTIR spectrum of $\left(\mathrm{C}_{6} \mathrm{H}_{11} \mathrm{NH}_{3}\right)_{4}\left[\mathrm{Ni}(\mathrm{NCS})_{6}\right] \cdot 2 \mathrm{H}_{2} \mathrm{O}$.

\section{Wavenumber, $\mathrm{cm}^{-1}$}

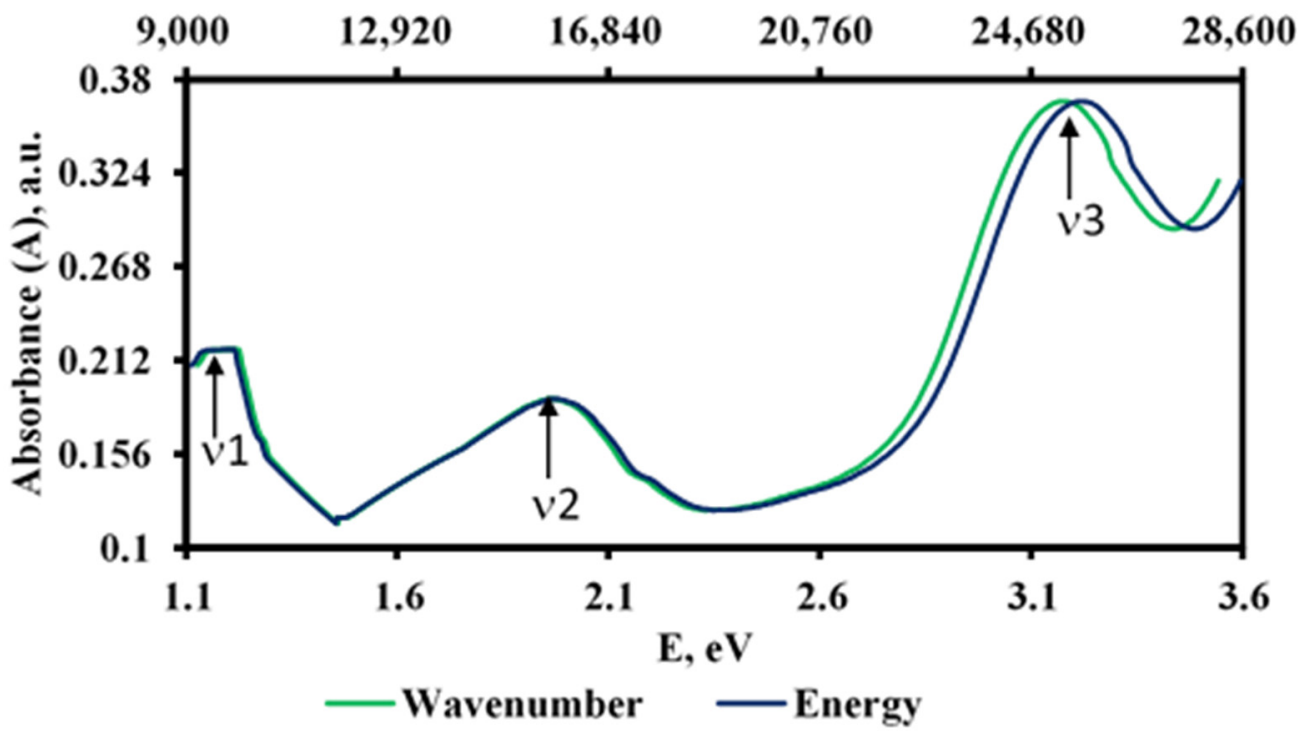

Figure 2. UV-Vis-NIR absorbance spectrum of $\left(\mathrm{C}_{6} \mathrm{H}_{11} \mathrm{NH}_{3}\right)_{4}\left[\mathrm{Ni}(\mathrm{NCS})_{6}\right] \cdot 2 \mathrm{H}_{2} \mathrm{O}$. 


\subsection{NMR Spectra Analyses}

The $1 \mathrm{H}$ - and 13C-NMR spectra of the new hybrid organic-inorganic compound of $\left(\mathrm{C}_{6} \mathrm{H}_{11} \mathrm{NH}_{3}\right)_{4}\left[\mathrm{Ni}(\mathrm{NCS})_{6}\right] \cdot 2 \mathrm{H}_{2} \mathrm{O}$ are displayed and discussed in the supplementary information (Figures S1 and S2; Tables S1 and S2).

\subsection{SCXRD Analyses}

At room temperature, the compound $\left(\mathrm{C}_{6} \mathrm{H}_{11} \mathrm{NH}_{3}\right)_{4}\left[\mathrm{Ni}(\mathrm{NCS})_{6}\right] \cdot 2 \mathrm{H}_{2} \mathrm{O}$ crystallizes in the monoclinic crystal system. The extinction conditions observed agree with the $P 2_{1} / c$ space group. Most of the atomic positions were found by using the superflip program. With isotropic atomic displacement parameters (ADPs), the residual factors converged to the value $R(F)=0.27, w R\left(F^{2}\right)=0.5432$, and $\mathrm{S}=4.95$ for 98 refined parameters and 6892 observed reflections. At this stage of the refinement, the chemical formula $\left(\mathrm{C}_{6} \mathrm{H}_{11} \mathrm{NH}_{3}\right)_{4}\left[\mathrm{Ni}(\mathrm{NCS})_{6}\right] \cdot 2 \mathrm{H}_{2} \mathrm{O}$ was not equilibrated. By refining the anisotropic ADPs of all the atoms, the residual factors converged to the value $R(F)=0.1044, w R\left(F^{2}\right)=0.252$, and $S=2.31$ for 223 refined parameters. The difference-Fourier maps showed very weak residues at distances close to $0.9 \AA$ from several carbon, nitrogen, and oxygen atoms and were attributed to the $\mathrm{H}$ atoms. Restrictions were applied on their positions and (ADPs) and the extinction parameter was refined. The chemical formula became $\left(\mathrm{C}_{6} \mathrm{H}_{11} \mathrm{NH}_{3}\right)_{4}\left[\mathrm{Ni}(\mathrm{NCS})_{6}\right] \cdot 2 \mathrm{H}_{2} \mathrm{O}$ and the residual factors decreased to the final values, given in the supplementary information. The atomic positions and the anisotropic ADPs are given in the supplementary information, respectively.

Since at room temperature very large ADPs were observed for most of the carbon atoms, a second set of data was collected at $120 \mathrm{~K}$. A large decrease of the cell volume from $2199.45(11)$ to $2134.77(11) \AA^{3}$ was observed without any change in the symmetry. Therefore, the room temperature structure was used as a starting model for the refinement of the low temperature structure. A significant decrease in the ADPs was observed. However, one of the two $\mathrm{C}_{6} \mathrm{H}_{14} \mathrm{~N}$ still showed large carbon ADPs. Consequently, these carbon atoms were split without any constraints on their ADPs and led to the final residual factors, given in Table 2. The atomic positions and the ADPs are given in the supplementary information (Tables S1-S4). Further details on the structure refinement may be obtained from the Cambridge Crystallographic Data Centre (CCDC), by quoting the Registry No. CCDC 2,131,541 [64].

The unit cell of the title compound $\left(\mathrm{C}_{6} \mathrm{H}_{11} \mathrm{NH}_{3}\right)_{4}\left[\mathrm{Ni}(\mathrm{NCS})_{6}\right] \cdot 2 \mathrm{H}_{2} \mathrm{O}$ consists of two formula units $(Z=2)$, each of which comprises two water molecules, the anionic complex of hexaisothiocyanatonickelate(II) (the inorganic moiety) and four cyclohexylammonium cations (the organic moiety). Half of the cations show disorder on the carbon atomic positions (see Figure 3). Selected bond lengths and angles are given in Table 3.

The hexaisothiocyanatonickelate(II) anion displayed a regular octahedron geometry. The angle value of $180^{\circ}$ was shown perfectly linear for $\mathrm{N}-\mathrm{Ni}-\mathrm{N}$ octahedron axis, while marginal deviations from linearity were shown as 179.0(1), 178.6(1), and 178.4(1) ${ }^{\circ}$ for the N1-C1-S1, N2-C2-S2, and N3-C3-S3 ligand angle values, respectively. These values were similar to those previously reported for this anionic complex with tetrakis(triethylammonium) cation [8]. Hydrogen bonds among cation, anion, and water molecules were observed. They interconnect these molecules to form a 2D-layered structure, as shown in Figure 4, where the crystal structure view, along the b-axis, illustrates clearly that each layer of the octahedral $\left[\mathrm{Ni}(\mathrm{NCS})_{6}\right]^{4-}$ is interacting with two layers of $\left(\mathrm{C}_{6} \mathrm{H}_{11} \mathrm{NH}_{3}\right)^{+}$. All possible hydrogen bonds are listed in Table 4 . 
Table 2. Experimental details.

\begin{tabular}{|c|c|c|}
\hline \multicolumn{3}{|c|}{ Crystal Data } \\
\hline Chemical formula & $\left(\mathrm{C}_{6} \mathrm{H}_{11} \mathrm{NH}_{3}\right)_{4}\left[\mathrm{Ni}(\mathrm{NCS})_{6}\right] \cdot 2 \mathrm{H}_{2} \mathrm{O}$ & $\left(\mathrm{C}_{6} \mathrm{H}_{11} \mathrm{NH}_{3}\right)_{4}\left[\mathrm{Ni}(\mathrm{NCS})_{6}\right] \cdot 2 \mathrm{H}_{2} \mathrm{O}$ \\
\hline$M_{\mathrm{r}}$ & 843.9 & 843.9 \\
\hline Crystal system, space group & Monoclinic, $P 2_{1} / c$ & Monoclinic, $P 2_{1} / c$ \\
\hline Temperature $(\mathrm{K})$ & 293 & 120 \\
\hline$a, b, c(\AA)$ & $15.8179(5), 10.6222(3), 13.8751(4)$ & $15.6486(5), 10.4641(3), 13.7387(4)$ \\
\hline$\beta\left({ }^{\circ}\right)$ & $109.362(1)$ & $108.393(1)$ \\
\hline$V\left(\AA^{3}\right)$ & $2199.45(11)$ & $2134.77(11)$ \\
\hline Z & 2 & 2 \\
\hline Radiation type & Mo $K \alpha$ & Mo $K \alpha$ \\
\hline$\mu\left(\mathrm{mm}^{-1}\right)$ & 0.76 & 0.79 \\
\hline Crystal size (mm) & $0.23 \times 0.19 \times 0.07$ & $0.23 \times 0.19 \times 0.07$ \\
\hline \multicolumn{3}{|c|}{ Data collection } \\
\hline Diffractometer & $\begin{array}{c}\text { D8 venture } \\
\text { diffractometer }\end{array}$ & $\begin{array}{l}\text { D8 venture } \\
\text { diffractometer }\end{array}$ \\
\hline Absorption correction & $\begin{array}{l}\text { Multi-scan } \\
\text { SADABS }\end{array}$ & $\begin{array}{l}\text { Multi-scan } \\
S A D A B S\end{array}$ \\
\hline$T_{\min }, T_{\max }$ & $0.694,0.747$ & $0.695,0.746$ \\
\hline $\begin{array}{l}\text { No. of measured, independent and } \\
\text { observed }[I>-4 \sigma(I)] \text { reflections }\end{array}$ & $39757,6892,6892$ & $31049,5537,5537$ \\
\hline$R_{\text {int }}$ & 0.028 & 0.026 \\
\hline$(\sin \theta / \lambda)_{\max }\left(\AA^{-1}\right)$ & 0.722 & 0.677 \\
\hline \multicolumn{3}{|c|}{ Refinement } \\
\hline$R\left[F^{2}>2 \sigma\left(F^{2}\right)\right], w R\left(F^{2}\right), \mathrm{S}$ & $0.072,0.168,1.54$ & $0.036,0.096,1.18$ \\
\hline No. of reflections & 6892 & 5537 \\
\hline No. of parameters & 230 & 277 \\
\hline No. of restraints & 3 & 2 \\
\hline H-atom treatment & $\begin{array}{l}\mathrm{H} \text { atoms treated by a mixture of } \\
\text { independent and constrained refinement }\end{array}$ & $\begin{array}{l}\mathrm{H} \text { atoms treated by a mixture of } \\
\text { independent and constrained refinement }\end{array}$ \\
\hline$\Delta \rho_{\max }, \Delta \rho_{\min }\left(\mathrm{e} \AA^{-3}\right)$ & $0.50,-0.39$ & $0.18,-0.23$ \\
\hline
\end{tabular}

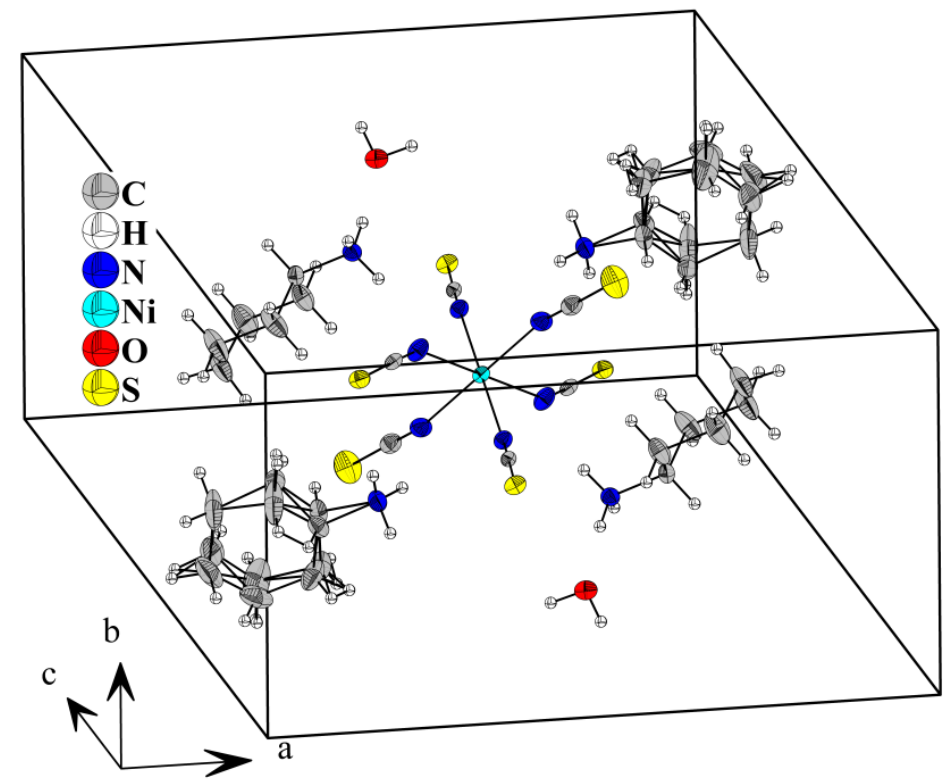

Figure 3. Perspective view of the unit cell of $\left(\mathrm{C}_{6} \mathrm{H}_{11} \mathrm{NH}_{3}\right)_{4}\left[\mathrm{Ni}(\mathrm{NCS})_{6}\right] \cdot 2 \mathrm{H}_{2} \mathrm{O}$ at $120 \mathrm{~K}$. 
Table 3. Selected angles and bond length of $\left(\mathrm{C}_{6} \mathrm{H}_{11} \mathrm{NH}_{3}\right)_{4}\left[\mathrm{Ni}(\mathrm{NCS})_{6}\right] \cdot 2 \mathrm{H}_{2} \mathrm{O}$.

\begin{tabular}{|c|c|c|c|c|c|c|}
\hline \multicolumn{3}{|c|}{ Bond Length $(\AA ̊)$} & \multicolumn{4}{|c|}{ Angles Degree } \\
\hline Ni1 & N1 & 2.092 & N1 & Ni1 & $\mathrm{N} 2$ & 86.77 \\
\hline Ni1 & N2 & 2.099 & $\mathrm{~N} 1$ & Ni1 & N3 & 89.30 \\
\hline Ni1 & N3 & 2.082 & N1 & Ni1 & N1 & 180.00 \\
\hline Ni1 & N1 & 2.092 & Ni1 & N1 & $\mathrm{C} 1$ & 146.4 \\
\hline Ni1 & N2 & 2.099 & Ni1 & N2 & $\mathrm{C} 2$ & 153.4 \\
\hline Ni1 & N3 & 2.082 & Ni1 & N3 & $\mathrm{C} 3$ & 156.4 \\
\hline N1 & $\mathrm{C} 1$ & $1.155(2)$ & N1 & $\mathrm{C} 1$ & $\mathrm{~S} 1$ & $179.0(1)$ \\
\hline N2 & $\mathrm{C} 2$ & $1.154(2)$ & $\mathrm{N} 2$ & $\mathrm{C} 2$ & S2 & $178.6(1)$ \\
\hline N3 & $\mathrm{C} 3$ & $1.153(2)$ & N3 & $\mathrm{C} 3$ & S3 & 178.4(1) \\
\hline $\mathrm{C} 1$ & $\mathrm{~S} 1$ & $1.630(1)$ & & & & \\
\hline $\mathrm{C} 2$ & S2 & $1.637(1)$ & & & & \\
\hline $\mathrm{C} 3$ & S3 & $1.620(1)$ & & & & \\
\hline
\end{tabular}

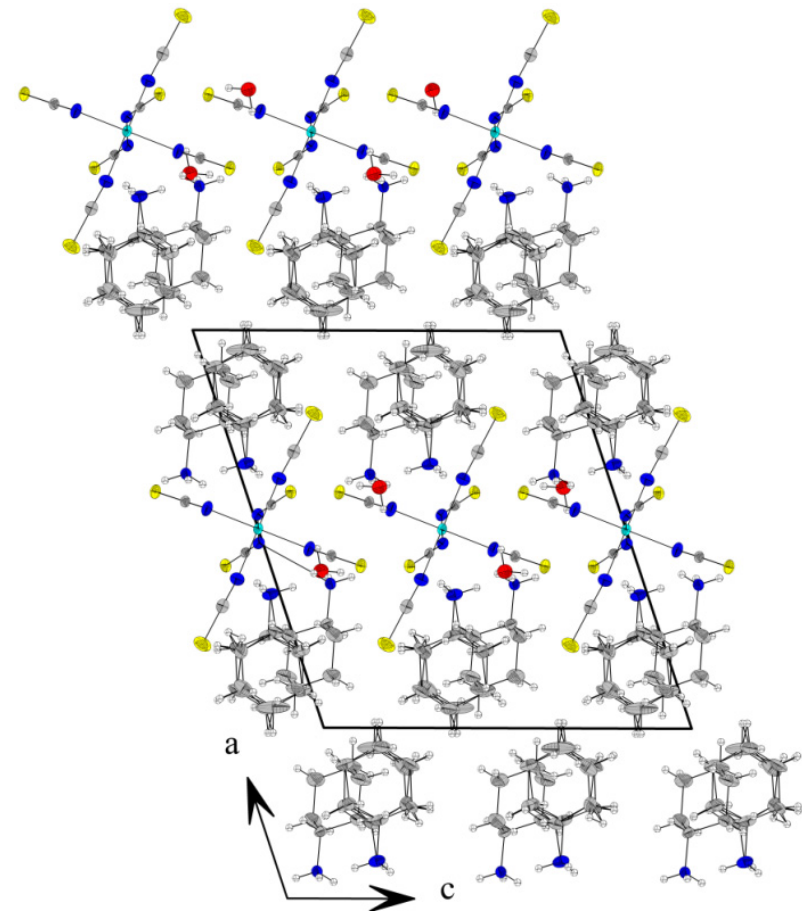

Figure 4. Projection view $\left(\mathrm{C}_{6} \mathrm{H}_{11} \mathrm{NH}_{3}\right)_{4}\left[\mathrm{Ni}(\mathrm{NCS})_{6}\right] \cdot 2 \mathrm{H}_{2} \mathrm{O}$ along the $b$-axis.

Table 4. List of possible hydrogen bonds at $120 \mathrm{~K}$ for $\left(\mathrm{C}_{6} \mathrm{H}_{11} \mathrm{NH}_{3}\right)_{4}\left[\mathrm{Ni}(\mathrm{NCS})_{6}\right] \cdot 2 \mathrm{H}_{2} \mathrm{O}$.

\begin{tabular}{ccccccc}
\hline Donor & Hydrogen & Acceptor & $\begin{array}{c}\text { D-H } \\
\text { Distance, } \\
\AA\end{array}$ & $\begin{array}{c}\text { H ... A } \\
\text { Distance, } \\
\AA\end{array}$ & $\begin{array}{c}\text { D-A } \\
\text { Distance, } \\
\AA\end{array}$ & $\begin{array}{c}\text { A-H ... D } \\
\text { Angle, }\end{array}$ \\
\hline O1 & H1O1 & S1 & $0.866(15)$ & $2.459(19)$ & $3.3043(14)$ & $166(3)$ \\
N5 & H2N5 & N1 & 0.87 & 2.35 & $3.0924(19)$ & 143.14 \\
N5 & H2N5 & N2 & 0.87 & 2.39 & $3.0791(17)$ & 135.97 \\
N5 & H3N5 & O1 & 0.87 & 1.97 & $2.8375(15)$ & 172.00 \\
N4 & H2N4 & N3 & 0.87 & 2.31 & $3.0838(18)$ & 148.52 \\
\hline
\end{tabular}

Three types of hydrogen bonds were observed in this crystal structure, as shown in Figure 5. The first type of interaction was the $\mathrm{N}-\mathrm{H} \cdots \mathrm{N}$ and corresponded to the hydrogen bond between ammonium cation and the thiocyanate nitrogen. The second type of interaction was the $\mathrm{N}-\mathrm{H} \cdots \mathrm{O}$ and corresponded to the bond between ammonium cation and a water molecule. The third type of interaction was the $\mathrm{O}-\mathrm{H} \cdots \mathrm{S}$ and corresponded to the bond between a water molecule and thiocyanate sulfur. The second and third hydrogen 
bonding types were only observed with the equatorial thiocyanate ligands. All these bonds, detected by SCXRD, were in agreement with the observed vibrational bands in the FTIR spectrum.

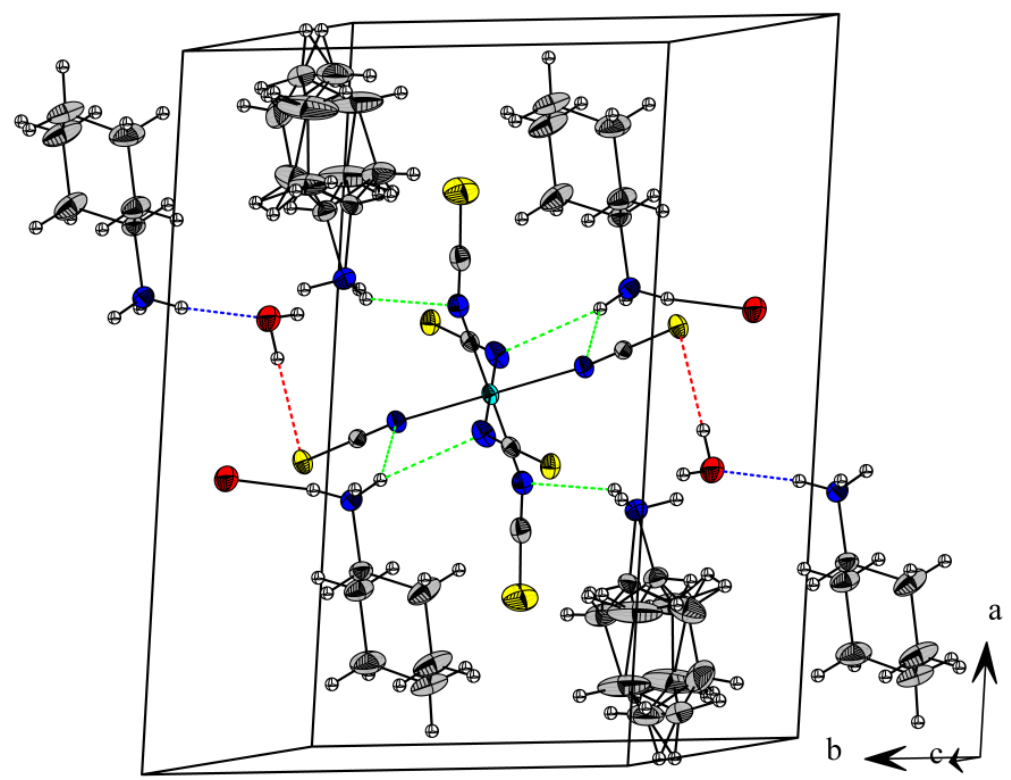

Figure 5. Hydrogen bonds in $\left(\mathrm{C}_{6} \mathrm{H}_{11} \mathrm{NH}_{3}\right)_{4}\left[\mathrm{Ni}(\mathrm{NCS})_{6}\right] \cdot 2 \mathrm{H}_{2} \mathrm{O}$ at $120 \mathrm{~K}$. The blue, green, and red dashed lines correspond to $\mathrm{N}-\mathrm{H} \cdots \mathrm{O}, \mathrm{N}-\mathrm{H} \cdots \mathrm{N}$, and $\mathrm{O}-\mathrm{H} \cdots \mathrm{S}$ hydrogen bonds, respectively.

At room temperature, the single crystal of $\left(\mathrm{C}_{6} \mathrm{H}_{11} \mathrm{NH}_{3}\right)_{4}\left[\mathrm{Ni}(\mathrm{NCS})_{6}\right] \cdot 2 \mathrm{H}_{2} \mathrm{O}$ compound showed a strong disorder in the doubly attached ring. For this reason, data were also collected at $120 \mathrm{~K}$. The atomic positions of the disordered structures collected at $293 \mathrm{~K}$ are given in Tables S3 and S5, while those collected at $120 \mathrm{~K}$ are displayed in Tables S4 and S6. As the low temperature measurement did not suppress the disorder, a theoretical ordered structure of $\left(\mathrm{C}_{6} \mathrm{H}_{11} \mathrm{NH}_{3}\right)_{4}\left[\mathrm{Ni}(\mathrm{NCS})_{6}\right] \cdot 2 \mathrm{H}_{2} \mathrm{O}$ was built. All the disordered atoms with partial occupancy were ordered manually in their average positions and considered full occupancy. This enabled us to simulate the $\mathrm{X}$-ray powder diffraction patterns for the disordered and ordered structures of $\left(\mathrm{C}_{6} \mathrm{H}_{11} \mathrm{NH}_{3}\right)_{4}\left[\mathrm{Ni}(\mathrm{NCS})_{6}\right] \cdot 2 \mathrm{H}_{2} \mathrm{O}$ by using the "Mercury" program, as shown in Figure 6A,B, respectively.

Figure 7a shows the distribution of all atoms inside the primitive cell except the hydrogen atoms, while Figure 6B gives an example of the disorder in the carbon atoms of cyclohexyl ring. The first pattern, shown in Figure 6A, was generated in the presence of complete disorder and the second one, shown in Figure 6B, was generated by removing only the disorder in the carbon of cyclohexyl ring. Comparing the two simulated patterns in Figure $6 \mathrm{~A}, \mathrm{~B}$ revealed that removing the disorder on the doubly attached carbons of the ring either reduced the intensities of most peaks or disappeared them. However, there were some exceptions of the observation, where the peak intensities at 2- $\theta \sim 10.8$ and 11.7 degrees were enhanced and a new peak was arisen at $\sim 11.25$ degrees, as the result of reducing the disorder. As the disorder was enhanced at $293 \mathrm{~K}$, where the XRPD experiment was conducted, we observed that the experimental XRPD pattern (Figure 6C) had more peaks than the simulated one and the two peaks at 10.8 and 11.7 degrees disappeared. The unit cell of the monoclinic lattice consists of two formula units. The structure of $\left(\mathrm{C}_{6} \mathrm{H}_{11} \mathrm{NH}_{3}\right)_{4}\left[\mathrm{Ni}(\mathrm{NCS})_{6}\right] \cdot 2 \mathrm{H}_{2} \mathrm{O}$ at $120 \mathrm{~K}$ deviated slightly from the standard of two formula units per primitive cell due to the disorder not only in the doubly attached rings, as shown in Figure $7 \mathrm{~b}$, but also in the number of other atoms in the primitive cell, as shown in Table 5. 


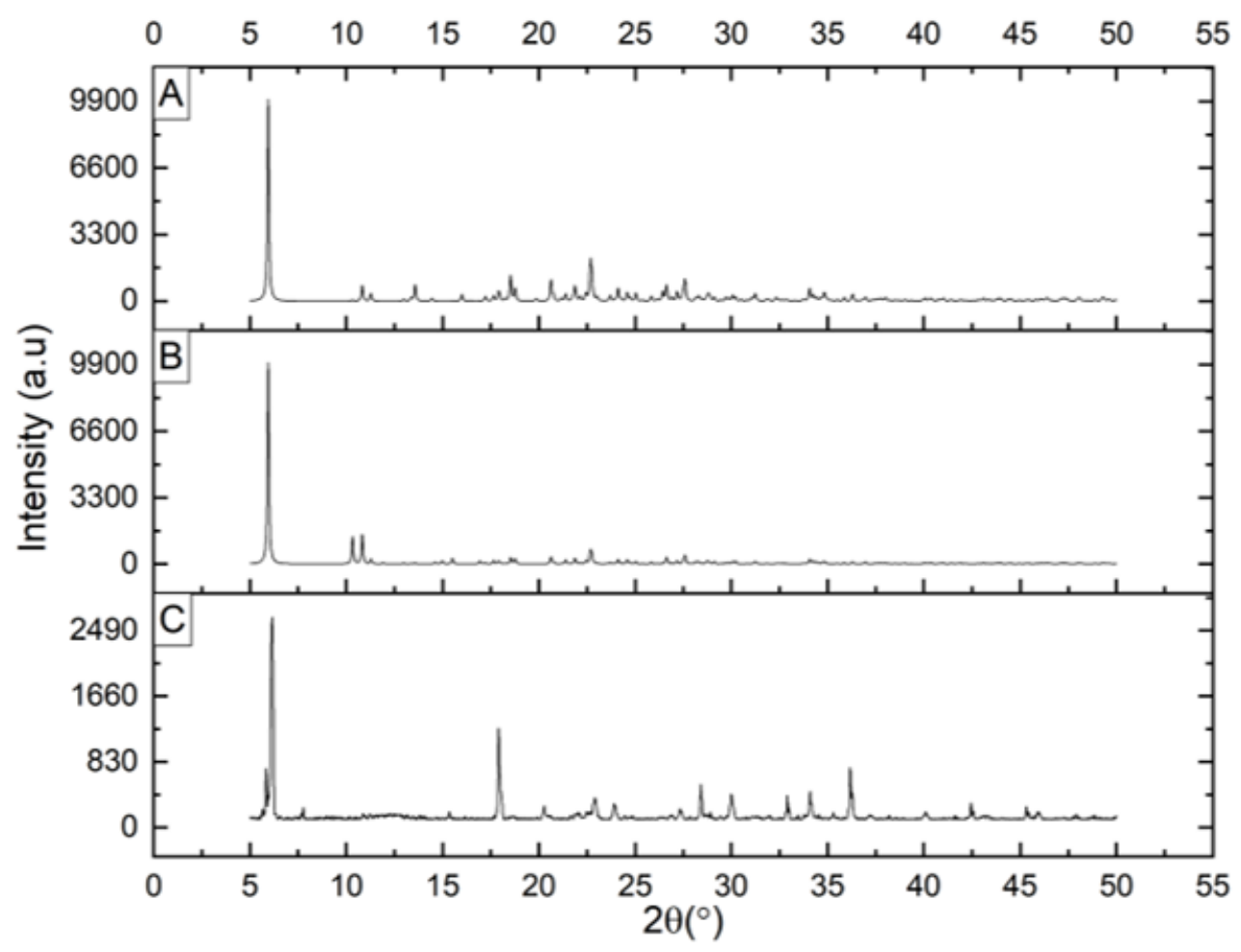

Figure 6. X-ray powder diffraction patterns: (A) the simulation based on the disordered structure of the doubly attached rings, (B) the simulation by removing the extra carbon atoms due to the disorder in the doubly attached rings, and $(C)$ the experimental for $\left(\mathrm{C}_{6} \mathrm{H}_{11} \mathrm{NH}_{3}\right)_{4}\left[\mathrm{Ni}(\mathrm{NCS})_{6}\right] \cdot 2 \mathrm{H}_{2} \mathrm{O}$.

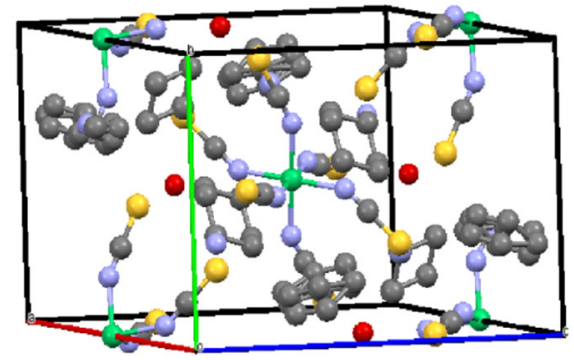

(a)

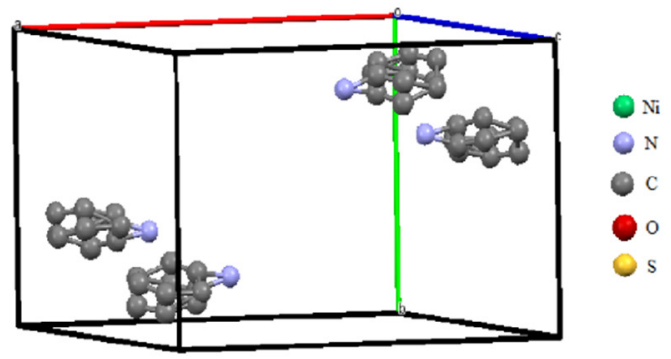

(b)

Figure 7. (a) Atomic distribution inside the primitive cell obtained from Mercury for all atoms except hydrogen atoms (b) disorder of the cyclohexylammonium six carbon atoms.

Table 5. The number of atoms in the primitive cell for the standard two lattice points per primitive cell case and the disordered one.

\begin{tabular}{ccc}
\hline Atom & Standard & Disorder \\
\hline O & 4 & 3 \\
C (radial) & 12 & 12 \\
C (ring) & 44 & 48 \\
$\mathrm{Ni}$ & 2 & 2 \\
$\mathrm{~N}$ & 20 & 20 \\
$\mathrm{~S}$ & 12 & 12 \\
\hline
\end{tabular}

The simulated X-ray diffraction pattern can be used as a reference standard when there is a good match between the simulated pattern of the structure and the experimental one. By comparing the experimental XRPD pattern (Figure 6C) with the simulated ones of Figure $6 \mathrm{~A}$ or Figure $6 \mathrm{~B}$, one can observe that the number of peaks of the experimental pattern exceeded those of the simulated ones due to the disorder in the number of carbon 
and oxygen atoms, as illustrated in Table 5, which obviously broke the standard of two formula units per primitive cell $[26,38]$. The more atoms, existing inside the primitive cell, might create different families of Bragg reflection planes, and consequently, generate more $X$-ray diffraction peaks. In addition, increasing the number of atoms inside the primitive cell produced Bragg reflection planes with smaller interplanar d-spacing or larger diffracted angles 2-theta. This explanation tells us why there were some peaks at the positions larger than $35^{\circ}$ in the experimental pattern, while they were absent in the simulated patterns. However, there were some peaks in the low 2-theta region that were absent in the simulated patterns such as the peaks at $\sim 5.8$ and 7.7 degrees. These peaks were not because of the presence of impurities due to the reactants of cyclohexylammonium thiocyanate, sodium thiocyanate, and nickel nitrate hexahydrate or the byproduct of sodium nitrate, as shown in Figure 8, which compares the XRD patterns of the reactants, byproduct, and experimental XRPD of our new hybrid organic-inorganic compound. Thus, we excluded the existence of impurities and concluded that the disorder might create new families of Bragg's reflection planes, which either led to forming new peaks or disappearing some others by constructive and destructive interferences.

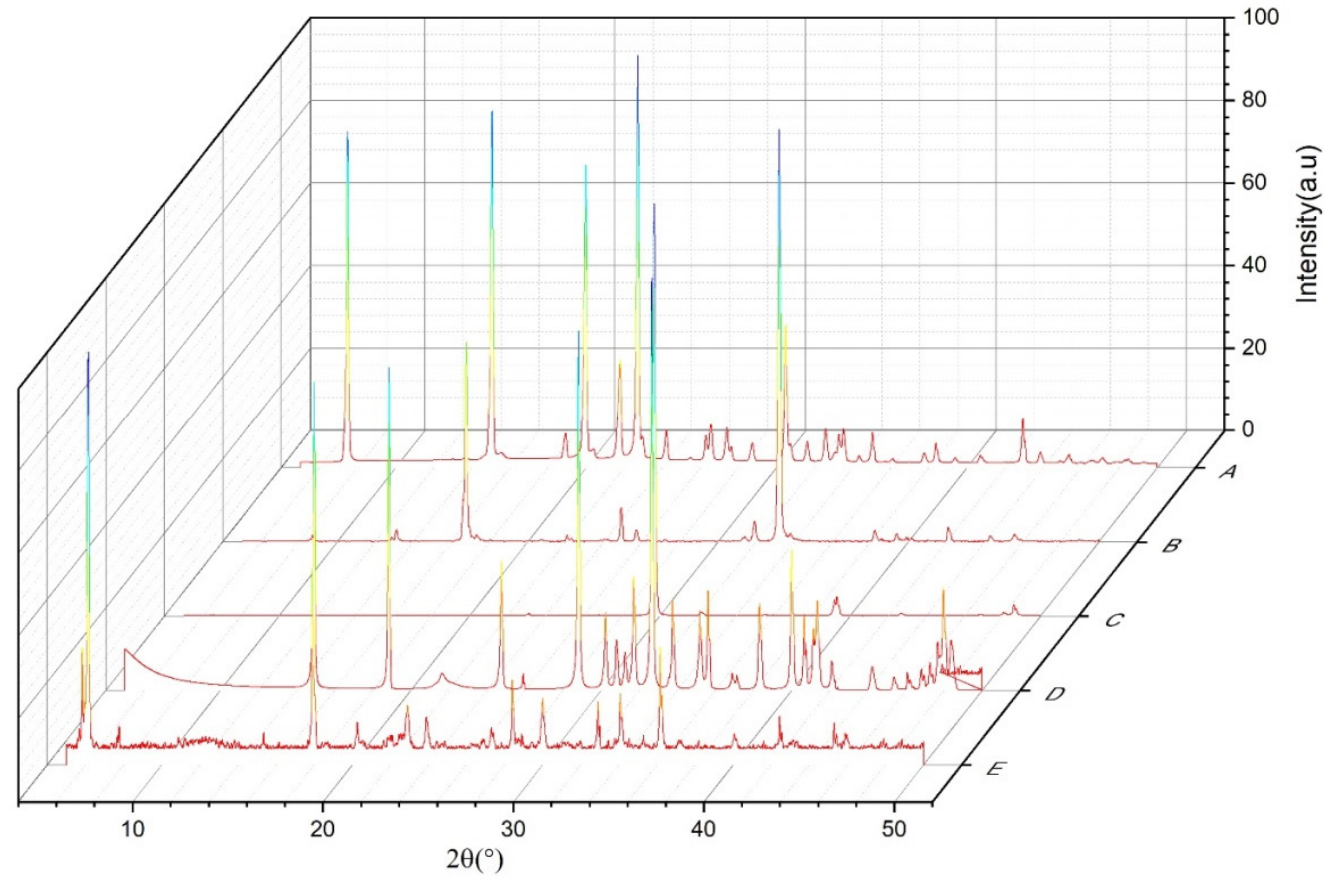

Figure 8. X-ray powder diffraction patterns of the reactants of cyclohexylammonium thiocyanate (A), sodium thiocyanate $(\mathbf{B})$, and nickel nitrate hexahydrate $(\mathbf{C})$, byproduct of sodium nitrate $(\mathbf{D})$, and the experimental of $\left(\mathrm{C}_{6} \mathrm{H}_{11} \mathrm{NH}_{3}\right)_{4}\left[\mathrm{Ni}(\mathrm{NCS})_{6}\right] \cdot 2 \mathrm{H}_{2} \mathrm{O}(\mathbf{E})$.

\subsection{TG Analysis}

The TGA showed two different multi-stage decomposition thermograms under air and helium, as shown in Figure 9. About $4.5 \%$ weight loss under both atmospheres was observed in the temperature range of $50-112{ }^{\circ} \mathrm{C}$, which could be due to the loss of two crystallization water molecules and the formation of the anhydrous form of the compound, $\left(\mathrm{C}_{6} \mathrm{H}_{11} \mathrm{NH}_{3}\right)_{4}\left[\mathrm{Ni}(\mathrm{NCS})_{6}\right]$. The second step, under helium, was observed as a sharp decay in the range of $112-200{ }^{\circ} \mathrm{C}$, accounting for $\sim 70.5 \%$ weight loss under helium due to the loss of all the four cations of cyclohexylammonium and three of the isothiocyanate ligands. The third step was observed in the range of $200-322^{\circ} \mathrm{C}$, accounting for $\sim 12 \%$ weight loss due to the loss of two isothiocyanate ligands. The fourth step was observed in the range of $322-437^{\circ} \mathrm{C}$ accounting for $\sim 2 \%$ weight loss under helium due to the loss of $\mathrm{CN}$ moiety and the formation of nickel sulfide (NiS) with a remaining weight percentage of 11.0 (calculated $10.75 \%)$. The formation of NiS was also confirmed by XRPD. 


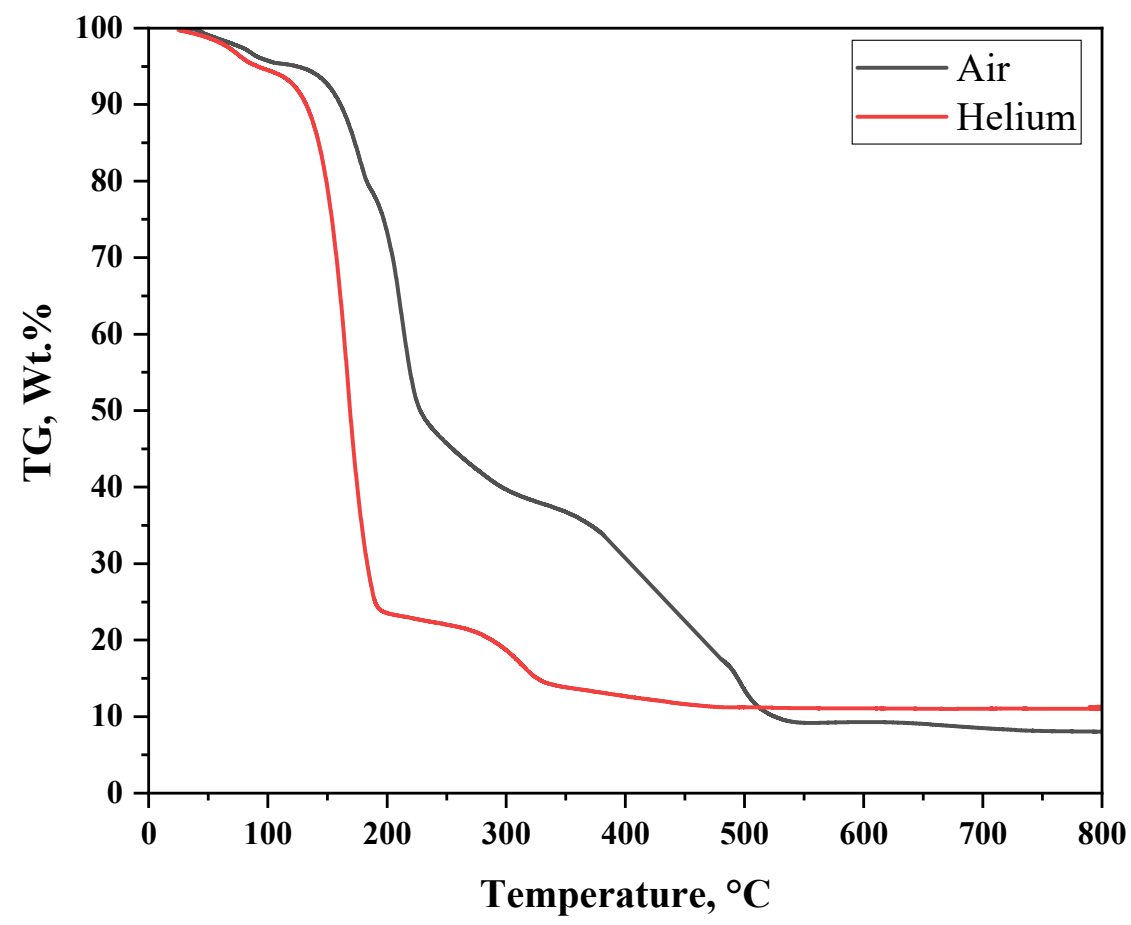

Figure 9. TGA analyses of $\left(\mathrm{C}_{6} \mathrm{H}_{11} \mathrm{NH}_{3}\right)_{4}\left[\mathrm{Ni}(\mathrm{NCS})_{6}\right] \cdot 2 \mathrm{H}_{2} \mathrm{O}$ under air (black) and helium (red).

On the other hand, the second step, under air, represented a loss of one cyclohexylammonium of $\sim 12 \%$ in the temperature range of $112-180{ }^{\circ} \mathrm{C}$. The third step could be attributed to the loss of the remaining three cyclohexylammonium $(\sim 35.6 \%)$ in the temperature range of $180-242{ }^{\circ} \mathrm{C}$. The fourth step corresponded to the loss of two isothiocyanate ligands between $242{ }^{\circ} \mathrm{C}$ and $375^{\circ} \mathrm{C}$. The last step could be owing to the loss of the remaining four isothiocyanate ligands and the formation of nickel oxide $(\mathrm{NiO})$ at $550{ }^{\circ} \mathrm{C}$ with a remaining weight percentage of $\sim 9.0$ (calculated $8.85 \%$ ). The formation of $\mathrm{NiO}$ was confirmed by XRPD, too.

\subsection{XRPD Microstructure of $\mathrm{NiO}$ and $\mathrm{NiS}$}

The XRD pattern, obtained after the pyrolysis of $\left(\mathrm{C}_{6} \mathrm{H}_{11} \mathrm{NH}_{3}\right)_{4}\left[\mathrm{Ni}(\mathrm{NCS})_{6}\right] \cdot 2 \mathrm{H}_{2} \mathrm{O}$ at $550{ }^{\circ} \mathrm{C}$ under air (Figure 10a), coincided with the XRPD pattern of cubic NiO. The peaks at $2 \theta=37.2,43.3,62.9,75.5$, and $79.6^{\circ}$, corresponded, respectively, to the crystallographic planes of (111), (200), (220), (511) and (222), as assigned by the (JCPDS card no. 47-1049) [65] (Figure 10a). No impurity peaks were observed in the pattern. Moreover, the relatively sharp XRD peaks indicated the formation of crystalline structure and the peak broadness connoted nanostructures. By applying the Scherrer equation, the crystallite size was calculated:

$$
D=\frac{0.9 \lambda}{\beta \cos \theta}
$$

The symbols $\lambda, \theta$, and $\beta$ stand for the wavelength of the $\mathrm{Cu} \mathrm{K} \alpha(1.5406 \AA)$, the diffraction angle, and the full width at half maximum (FWHM) in radians, respectively. By using the highest intensity peaks of (111), (200), and (220), an average $D$ value of $16.34 \mathrm{~nm}$ was obtained. The $d$-spacing $(d)$, the lattice parameter $(a)$, and the microstrain $(\varepsilon)$ were obtained by using Equations (2)-(4), respectively [66].

$$
\begin{gathered}
d=\frac{\lambda}{2 \sin \theta} \\
d=\frac{a}{\sqrt{h^{2}+k^{2}+l^{2}}}
\end{gathered}
$$




$$
\varepsilon=\frac{\beta}{4 \tan \theta}
$$

The tabulated values (Table 6) are in agreement with previous data.

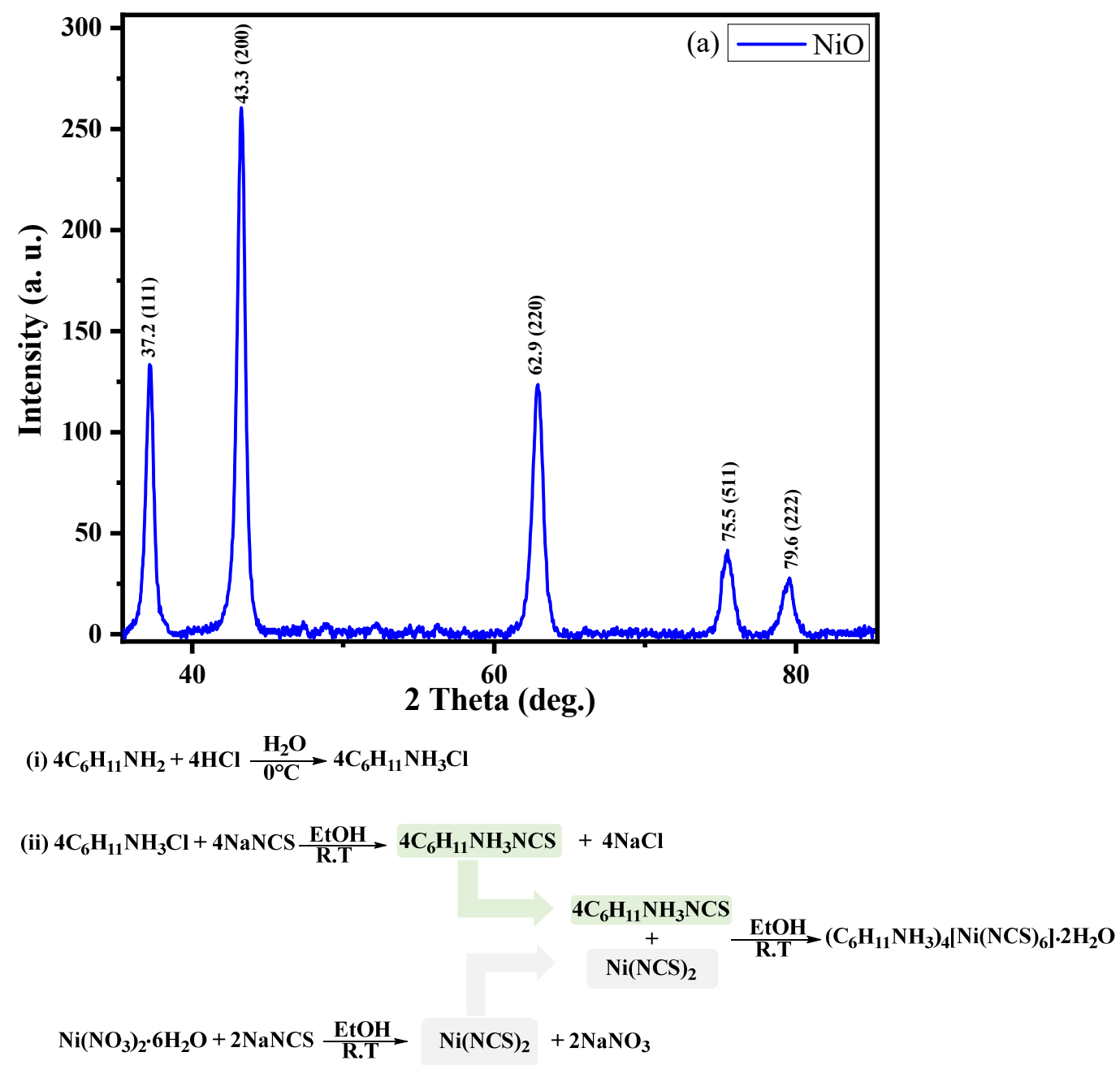

Figure 10. $\mathrm{XRD}$ patterns of (a) $\mathrm{NiO}$ and (b) $\mathrm{NiS}$, obtained after the pyrolysis of $\left(\mathrm{C}_{6} \mathrm{H}_{11} \mathrm{NH}_{3}\right)_{4}\left[\mathrm{Ni}(\mathrm{NCS})_{6}\right] \cdot 2 \mathrm{H}_{2} \mathrm{O}$ under air at $550{ }^{\circ} \mathrm{C}$ and helium at $500{ }^{\circ} \mathrm{C}$, respectively.

Table 6. Crystallite size and lattice parameters of $\mathrm{NiO}$ and NiS.

\begin{tabular}{|c|c|c|c|c|c|c|c|c|}
\hline \multirow{2}{*}{ Sample } & \multirow{2}{*}{$\beta$} & \multirow{2}{*}{$D(\mathrm{~nm})$} & \multirow{2}{*}{$D^{*}(\mathrm{~nm})$} & \multirow{2}{*}{$d(\AA)$} & \multicolumn{2}{|c|}{ L. Parameters } & \multirow{2}{*}{$\varepsilon$} & \multirow{2}{*}{$\varepsilon^{*}$} \\
\hline & & & & & $\mathbf{a}$ & c & & \\
\hline $\mathrm{NiO}$ & 0.5027 & 16.34 & 30.80 & 2.2530 & 4.180 & & 0.0055 & 0.0026 \\
\hline $\mathrm{NiS}$ & 0.2077 & 53.79 & 72.98 & 2.3050 & 3.421 & 5.322 & 0.0021 & 0.0015 \\
\hline
\end{tabular}

$D^{*}$ (crystallite size) and $\varepsilon^{*}$ (microstrain) calculated by the Williamson-Hall method.

The XRD pattern in Figure $10 \mathrm{~b}$, obtained after the pyrolysis of $\left(\mathrm{C}_{6} \mathrm{H}_{11} \mathrm{NH}_{3}\right)_{4}\left[\mathrm{Ni}(\mathrm{NCS})_{6}\right] \cdot 2 \mathrm{H}_{2} \mathrm{O}$ at $500{ }^{\circ} \mathrm{C}$ under helium, matched well with the JCPDS reference $01-075-0613$ of the rhombohedral $\alpha-\mathrm{NiS}$. The peaks at $2 \theta=30.2,34.7,45.8,53.5$, $60.7,62.6,63.2,66.6$, and $70.5^{\circ}$ corresponded to the crystallographic plane of (100), (101), (102), (110), (103), (200), (201), (004), and (202), respectively [67]. The relatively high crystallinity of the synthesized $\alpha-\mathrm{NiS}$ nanocrystalline was evidenced by the relatively sharp peaks of the pattern, while their less broadening reflected large size NPs. The average crystallite size $(D)$ was estimated to be $53.79 \mathrm{~nm}$, considering the high intensity peaks: 
(100), (101), (102) and (110). The lattice parameters $a$ and $c$ were calculated according to the expression [68]:

$$
\frac{1}{d_{h k l}^{2}}=\frac{4}{3}\left(\frac{h^{2}+h k+k^{2}}{a^{2}}\right)+\frac{l^{2}}{c^{2}}
$$

To calculate the microstrain of the nanocrystalline $\mathrm{NiO}$ and NiS, the uniform deformation model UDM of the Williamson-Hall method, presuming crystals isotropicity, was used, as given in Equation (6) [69]. This method implies that the properties are independent of the crystallographic direction of measurement.

$$
\beta_{h k l} \cos \theta_{h k l}=\frac{k \lambda}{D}+4 \varepsilon \sin \theta_{h k l}
$$

Plotting $\beta_{h k l} \cos \theta_{h k l}$ against $4 \sin \theta_{h k l}$ (Figure 11a,b) provides linear relationship, where the slope and intercept can provide the microstrain and the crystallite size, respectively. For $\mathrm{NiO}$ and $\mathrm{NiS}$, the crystallite sizes $\left(D^{*}\right)$ were 30.80 and $72.98 \mathrm{~nm}$, respectively, while the microstrain $(\varepsilon)$ values were 0.0026 for $\mathrm{NiO}$ and 0.0015 for $\mathrm{NiS}$. The difference in the average crystallite sizes, estimated via Scherrer's and W-H methods can be attributed to the deviation in particle size distribution averaging, as more peaks are considered in the latter [70].

\subsection{Morphological Study}

Figure 12A portrays the SEM image of slightly aggregated quasi-spherical $\mathrm{NiO}$ particles of an almost uniform size of $70 \mathrm{~nm}$ [71]. The EDX spectrum (Figure 12B) confirmed the formation of the $\mathrm{NiO}$, as manifested by the sharp peaks at the binding energy of $\mathrm{Ni}$ and $\mathrm{O}$. The presence of carbon in the EDX spectrum might be attributed to the carbon tape, used to mount the sample on the SEM holder. Figure 12C shows that the NiS forms flake-like structures. Vijaya et al. [72] attributed the formation of nano-flakes to the electrostatic interactions and van der Waals forces, which caused the nanoparticles to aggregate as nanosheets and then to nanoflakes-like owing to the alteration of nucleation rate. The elemental composition of the NiS (Figure 12D) is portrayed as Ni and S peaks, supporting the formation of $\mathrm{NiS}$ with the 1:1 stoichiometry of $\mathrm{Ni}$ and $\mathrm{S}$ in the nanostructures.

\subsection{Porosity Analysis}

The $\mathrm{N}_{2}$ adsorption-desorption measurements, at liquid $\mathrm{N}_{2}$ temperature of $77 \mathrm{~K}$, were performed to determine the specific surface area and to probe the mesoporosity and the textural characteristics of the fabricated $\mathrm{NiO}$ and $\mathrm{NiS}$. The as-recorded adsorption-desorption isotherms are displayed in Figure 13A $(\mathrm{NiO})$ and Figure 13B $(\mathrm{NiS})$, where the isotherms suggested archetypal type-II sorption patterns with type- $\mathrm{H}_{3}$ hysteresis loops, indicating mesoporous nanostructures as per the IUPAC definition [73], which was additionally substantiated by the Barrett-Joyner-Halenda (BJH) pore size distribution of 7.0 and $10 \mathrm{~nm}$ for $\mathrm{NiO}$ and $\mathrm{NiS}$, respectively. The prominent step at the adsorption branch combined with the sharp decay of the desorption branch was concrete evidence of mesoporous material [74]. A sudden increase in the adsorbed $\mathrm{N}_{2}$, perceived at $P / P_{0}$ greater than 0.8 , is commonly linked to the capillary condensation, designating good sample homogeneity and relatively smaller pore size, as the $P / P_{0}$ inflection point is influenced by the pore size. The textural properties of the nanocrystalline mesoporous $\mathrm{NiO}$ and $\mathrm{NiS}$ samples are provided in Table 7. The results demonstrated that $\mathrm{NiO}$ had enhanced porosity, as reflected by larger BET surface area, pore volume, and pore size. A similar dramatically increased porosity of $\mathrm{NiO}$ NPs was attributed to the removal of surfactant residues and hydroxyl groups out of the pore system during calcination [75]. For both isotherms, the adsorption and desorption isotherms completely overlapped in the low and intermediate relative pressure ranges for $\mathrm{NiO}$, and the hysteresis loop subsists in the high relative pressure region $\left(P / P_{0}>0.8\right)$, which was mainly due to the presence of ink-bottle type and/or slit-shaped pores. Such ink-bottle type of pores possess a larger pore size in the bottle body, leading to the occurrence of 
hysteresis in the high relative pressure region [76]. On the other hand, no hysteresis loop was observed for NiS, indicating cylindrical closed-end pores, as per the Kelvin equation, which conjectures the similarity of the condensed phase and the uniform bulk liquid at the interface, separating the dense adsorbate region and the gas-like region, when the pore fills as when it empties. This phenomenon results in the coincidence of the desorption branch of open pores with the adsorption branch of the closed-end pores, and thus, no hysteresis loop exists [77].
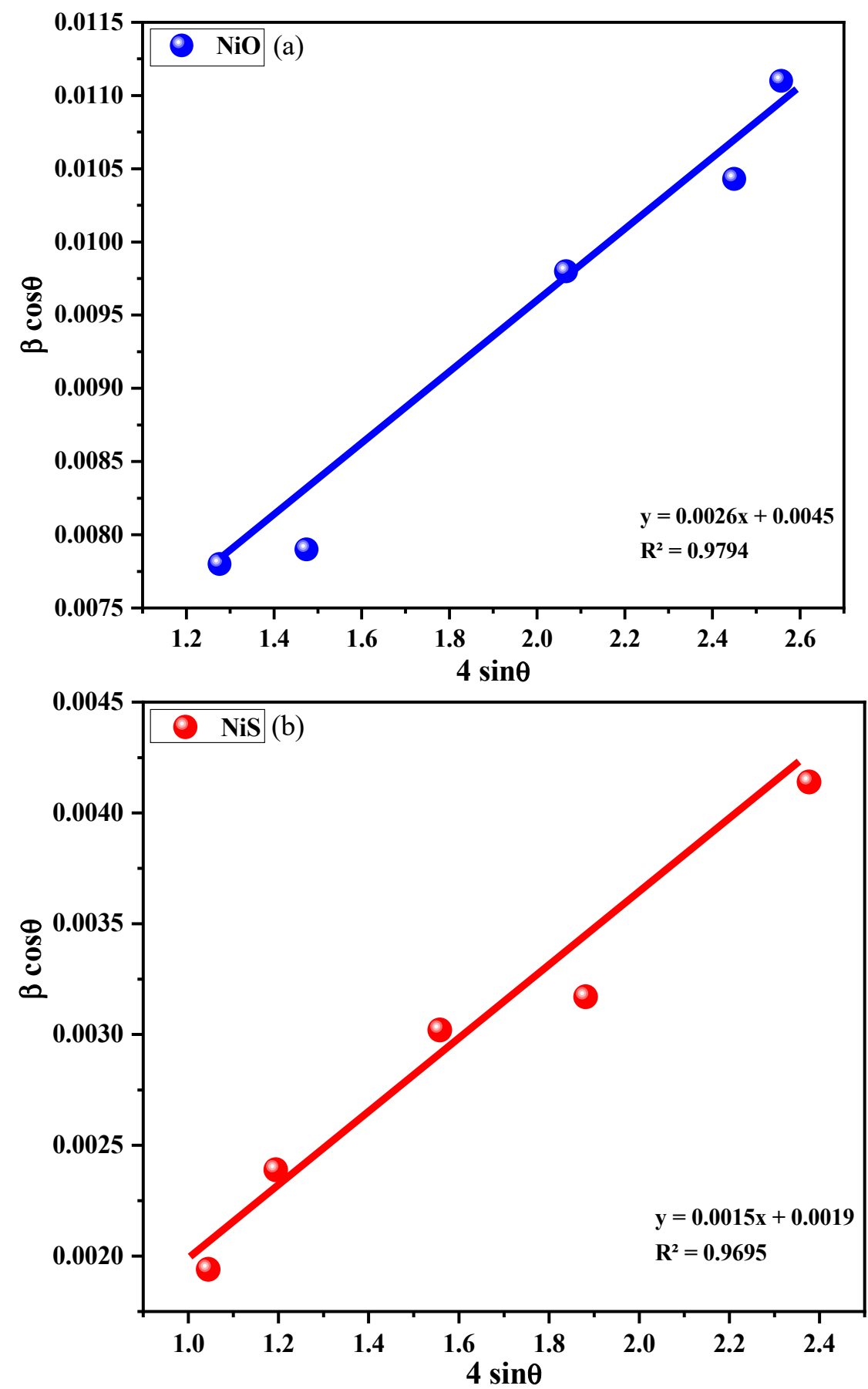

Figure 11. William-Hall plots for (a) $\mathrm{NiO}$ and (b) $\mathrm{NiS}$. 

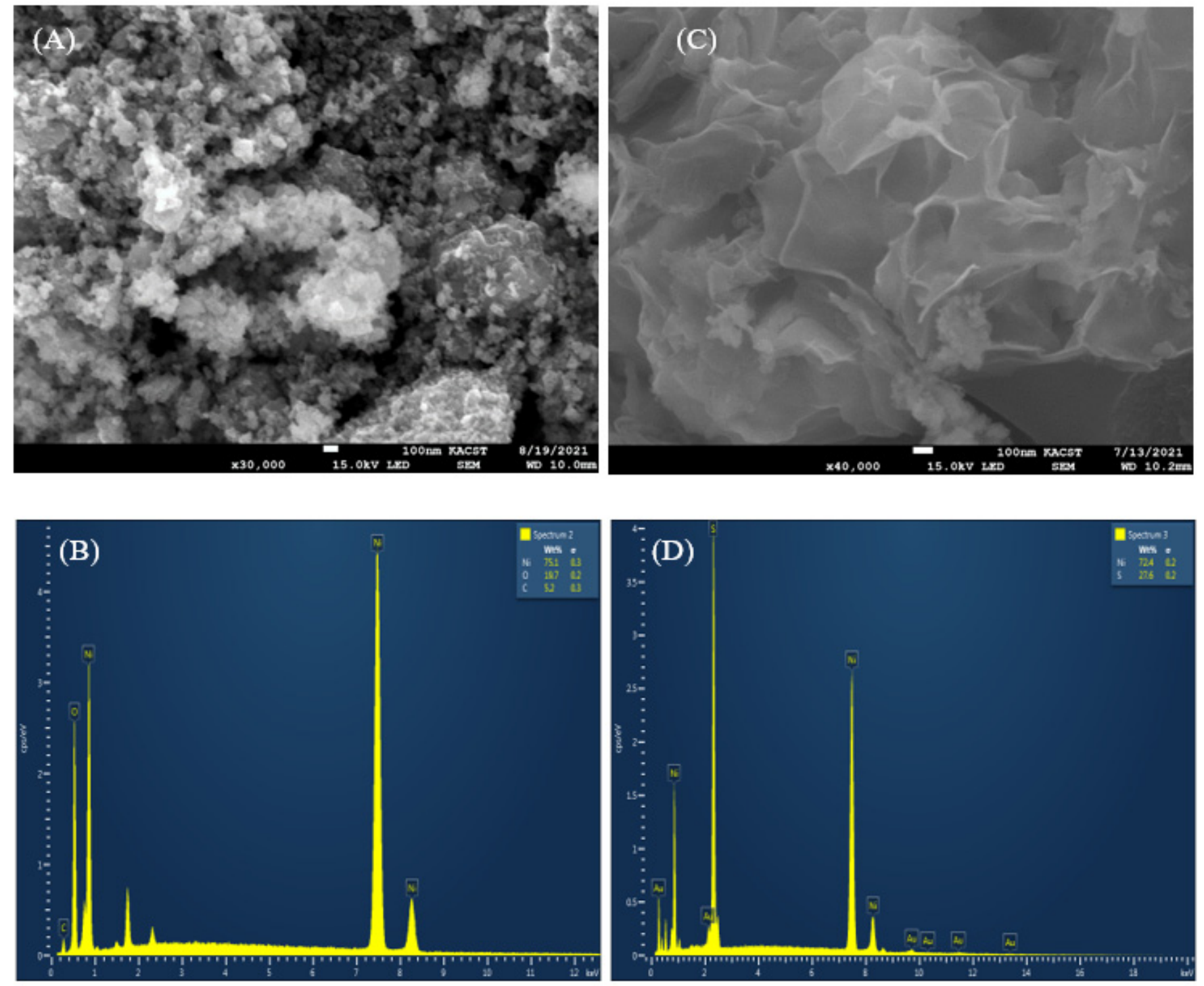

Figure 12. SEM (A) and EDX (B) of NiO; and SEM (C) and EDX (D) of NiS.

Table 7. Specific surface area and porosity parameters of $\mathrm{NiO}$ and NiS.

\begin{tabular}{cccc}
\hline Sample & $\mathbf{S}_{\text {BET }}\left(\mathbf{m}^{2} / \mathbf{g}\right)$ & Pore Volume $\left(\mathrm{cm}^{3} / \mathbf{g}\right)$ & Pre Size, $(\AA)$ \\
\hline $\mathrm{NiO}$ & 451.45 & 0.472 & 53.33 \\
$\mathrm{NiS}$ & 219.92 & 0.170 & 45.96 \\
\hline
\end{tabular}



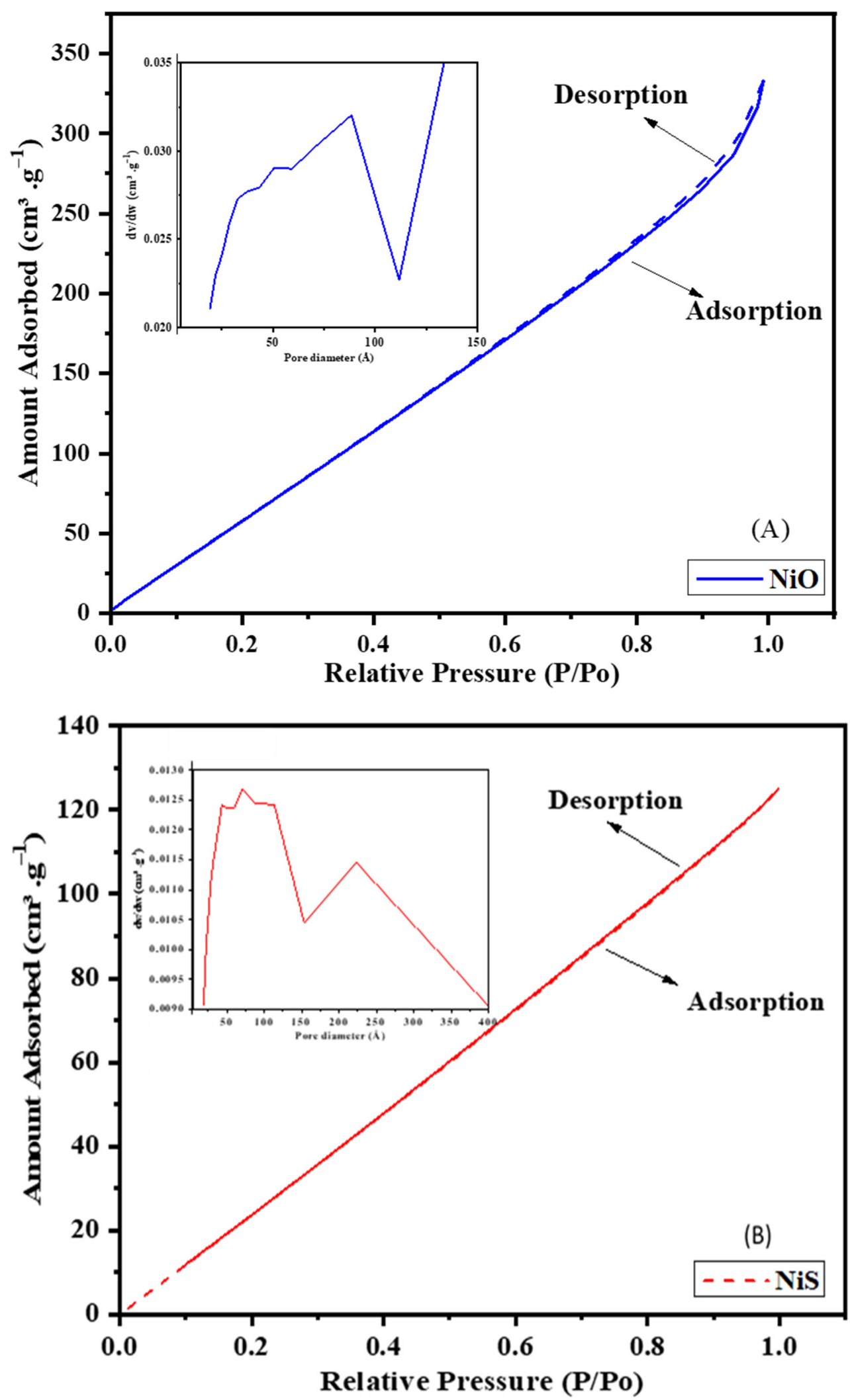

Figure 13. $\mathrm{N}_{2}$-physisorption of $\mathrm{NiO}$ and $\mathrm{NiS}$ isotherms (pore size distributions are shown in insets).

\section{Conclusions}

The novel hybrid organic-inorganic compound cyclohexylammonioum hexaisothiocyanatonickelate(II) dihydrate was synthesized at room temperature in four reaction steps with an overall yield of $93 \%$. The title compound has been characterized fully by 
spectroscopic techniques, the crystal and molecular structures have been determined at 295 and $120 \mathrm{~K}$. High surface area, mesoporous, nanocrystalline nickel oxide, and sulfide were obtained by pyrolysis in air and helium, respectively. These results show that cyclohexylammonioum hexaisothiocynatonickelate(II) is a promising single-source precursor for the facile production of mesoporous, nanocrystallined $\mathrm{NiO}$ and $\mathrm{NiS}$ for application-oriented research

Supplementary Materials: The following supporting information can be downloaded at: https: / / www.mdpi.com/article/10.3390/cryst12030315/s1, Figure S1: ${ }^{1} \mathrm{H}-\mathrm{NMR}$ spectrum of $\left(\mathrm{C}_{6} \mathrm{H}_{11} \mathrm{NH}_{3}\right)_{4}\left[\mathrm{Ni}(\mathrm{NCS})_{6}\right] \cdot 2 \mathrm{H}_{2} \mathrm{O}$ in methanol-d ${ }^{4}$; Figure $\mathrm{S} 2:{ }^{13} \mathrm{C}-\mathrm{NMR}$ spectrum of $\left(\mathrm{C}_{6} \mathrm{H}_{11} \mathrm{NH}_{3}\right)_{4}\left[\mathrm{Ni}(\mathrm{NCS})_{6}\right] \cdot 2 \mathrm{H}_{2} \mathrm{O}$ in methanol-d $\mathrm{d}^{4}$; Table S1: ${ }^{1} \mathrm{H}-\mathrm{NMR}$ of $\left(\mathrm{C}_{6} \mathrm{H}_{11} \mathrm{NH}_{3}\right)_{4}\left[\mathrm{Ni}(\mathrm{NCS})_{6}\right] \cdot 2 \mathrm{H}_{2} \mathrm{O}$ at room temperature; Table S2: ${ }^{13} \mathrm{C}-\mathrm{NMR}$ of $\left(\mathrm{C}_{6} \mathrm{H}_{11} \mathrm{NH}_{3}\right)_{4}\left[\mathrm{Ni}(\mathrm{NCS})_{6}\right] \cdot 2 \mathrm{H}_{2} \mathrm{O}$ at room temperature; Table S3: Atomic coordinates and isotropic displacement parameters (in $\AA^{2}$ ) at $293 \mathrm{~K}$; Table S4: Atomic coordinates and isotropic displacement parameters (in $\AA^{2}$ ) at $120 \mathrm{~K}$; Table S5: Anisotropic displacement parameters (in $\AA^{2}$ ) at $293 \mathrm{~K}$; Table S6: Anisotropic displacement parameters (in $\AA^{2}$ ) at $120 \mathrm{~K}$.

Author Contributions: Conceptualization, M.F.A.A. and A.B.; methodology, S.A., R.A., I.A., F.A. (Fahad Albaqi), K.A. and A.B.; software, H.B.Y. and A.A.; validation, H.B.Y.; formal analysis, M.F.A.A., A.M.B., H.B.Y., A.A., R.A., I.A., F.A. (Fahad Albaqi), K.A., K.T. and A.B.; investigation, M.F.A.A., R.A., K.T. and A.B.; data curation, S.A., R.A., I.A., F.A. (Fahad Albaqi) and K.A.; writing-original draft preparation, A.M.B., A.A., F.A. (Fahad Alqahtani), K.T. and A.B.; writing-review and editing, M.F.A.A., H.B.Y., A.A., F.A. (Fahad Alqahtani), A.M.A., K.T. and A.B.; project administration, A.M.B. and A.B.; funding acquisition, A.M.A. and A.B. All authors have read and agreed to the published version of the manuscript.

Funding: This research was funded by [Deputyship for Research \& Innovation, Ministry of Education in Saudi Arabia] grant number [375213500] and The APC was funded by [Ministry of Education].

Institutional Review Board Statement: Not applicable.

Informed Consent Statement: Not applicable.

Data Availability Statement: Data sharing is not applicable to this article.

Acknowledgments: Authors greatly thank all efforts made by our colleagues in QEERI, Hamad Bin Khalifa University, Doha, Qatar for conducting the single crystal measurement in their facilities.

Conflicts of Interest: The authors declare no conflict of interest.

\section{References}

1. Nazeeruddin, M.K.; Baranoff, E.; Grätzel, M. Dye-sensitized solar cells: A brief overview. Sol. Energy 2011, 85, 1172-1178. [CrossRef]

2. Prananto, Y.P.; Urbatsch, A.; Moubaraki, B.; Murray, K.S.; Turner, D.R.; Deacon, G.B.; Batten, S.R. Transition metal thiocyanate complexes of picolylcyanoacetamides. Aust. J. Chem. 2017, 70, 516-528. [CrossRef]

3. Kabesova, M. Structure and classification of thiocyanates and the mutual influence of their ligands. Chem. Zvesti. 1980, 34, 800-841.

4. Wöhlert, S.; Runčevski, T.; Dinnebier, R.E.; Ebbinghaus, S.G.; Näther, C. Synthesis, Structures, Polymorphism, and Magnetic Properties of Transition Metal Thiocyanato Coordination Compounds. Cryst. Growth Des. 2014, 14, 1902-1913. [CrossRef]

5. Hannachi, A.; Valkonen, A.; Gómez García, C.J.; Rzaigui, M.; Smirani, W. Synthesis of isomorphous cobalt and nickel thiocyanate coordination compounds: Effect of metals on compound properties. Polyhedron 2019, 173, 114122. [CrossRef]

6. Lusi, M.; Barbour, L.J. Solid-vapor sorption of xylenes: Prioritized selectivity as a means of separating all three isomers using a single substrate. Angew. Chem. 2012, 124, 3994-3997. [CrossRef]

7. Lago, E.L.; Seijas, J.A.; de Pedro, I.; Fernández, J.R.; Vázquez-Tato, M.P.; González, J.A.; Rilo, E.; Segade, L.; Cabeza, O.; Fernández, C.D.R. Structural and physical properties of a new reversible and continuous thermochromic ionic liquid in a wide temperature interval: [BMIM] $]_{4}\left[\mathrm{Ni}(\mathrm{NCS})_{6}\right]$. N. J. Chem. 2018, 42, 15561-15571. [CrossRef]

8. Kruger, P.; McKee, V. Tetrakis (triethylammonium) Hexakis (isothiocyanato-N) nickel (II). Acta Crystallogr. Sect. C Cryst. Struct. Commun. 1996, 52, 617-619. [CrossRef]

9. House, J., Jr.; Marquardt, L.A. Synthesis and thermal decomposition of piperidinium hexathiocyanatonickelate (II). Thermochim. Acta 1989, 153, 231-236. [CrossRef] 
10. Vijayakanth, T.; Ram, F.; Praveenkumar, B.; Shanmuganathan, K.; Boomishankar, R. Piezoelectric Energy Harvesting from a Ferroelectric Hybrid Salt $\left[\mathrm{Ph}_{3} \mathrm{MeP}_{4}\left[\mathrm{Ni}(\mathrm{NCS})_{6}\right]\right.$ Embedded in a Polymer Matrix. Angew. Chem. Int. Ed. 2020, 59, 10368-10373. [CrossRef]

11. Liu, J.Y.; Zhang, S.Y.; Zeng, Y.; Shu, X.; Du, Z.Y.; He, C.T.; Zhang, W.X.; Chen, X.M. Molecular Dynamics, Phase Transition and Frequency-Tuned Dielectric Switch of an Ionic Co-Crystal. Angew. Chem. 2018, 130, 8164-8168. [CrossRef]

12. Larue, B.; Tran, L.-T.; Luneau, D.; Reber, C. Crystal structures, magnetic properties, and absorption spectra of nickel (II) thiocyanato complexes: A comparison of different coordination geometries. Can. J. Chem. 2003, 81, 1168-1179. [CrossRef]

13. Brinzari, T.; Tian, C.; Halder, G.; Musfeldt, J.; Whangbo, M.-H.; Schlueter, J. Color properties and structural phase transition in penta-and hexacoordinate isothiocyanato $\mathrm{Ni}$ (II) compounds. Inorg. Chem. 2009, 48, 7650-7658. [CrossRef]

14. Lis, T.; Jerzykiewicz, L.B. Potassium D-3-phosphoglycerate and cyclohexylammonium D-3-phosphoglycerate hydrate. Acta Crystallogr. Sect. C Cryst. Struct. Commun. 1995, 51, 1001-1005. [CrossRef]

15. Kolev, T.; Koleva, B.; Seidel, R.W.; Spiteller, M.; Sheldrick, W.S. Cyclohexylammonium hydrogensquarate hemihydrate. Acta Crystallogr. Sect. Sect. E Struct. Rep. Online 2007, 63, o4852. [CrossRef]

16. Billing, D.G.; Lemmerer, A. Inorganic-organic hybrid materials incorporating primary cyclic ammonium cations: The lead bromide and chloride series. CrystEngComm 2009, 11, 1549-1562. [CrossRef]

17. Wei, X.; Li, J.; Yin, H. Bis(cyclohexylammonium) 2,2'-disulfanediyldibenzoate. Acta Crystallogr. Sect. E Struct. Rep. Online 2011, 67, o319. [CrossRef]

18. Sarr, M.; Merkens, C.; Diassé-Sarr, A.; Diop, L.; Englert, U. Bis(cyclohexylammonium) tetrachloridodiphenylstannate (IV). Acta Crystallogr. Sect. Sect. E Struct. Rep. Online 2014, 70, m220-m221. [CrossRef]

19. Bagabas, A.A.; Aboud, M.F.; Shemsi, A.M.; Addurihem, E.S.; Al-Othman, Z.A.; Kumar, C.; Fun, H.-K. Cyclohexylammonium nitrate. Acta Crystallogr. Sect. E Struct. Rep. Online 2014, 70, o253-o254. [CrossRef]

20. Liao, W.-Q.; Ye, H.-Y.; Fu, D.-W.; Li, P.-F.; Chen, L.-Z.; Zhang, Y. Temperature-Triggered Reversible Dielectric and Nonlinear Optical Switch Based on the One-Dimensional Organic-Inorganic Hybrid Phase Transition Compound $\left[\mathrm{C}_{6} \mathrm{H}_{11} \mathrm{NH}_{3}\right] \cdot 2 \mathrm{CdCl}_{4}$. Inorg. Chem. 2014, 53, 11146-11151. [CrossRef]

21. Sathya, P.; Anantharaja, M.; Elavarasu, N.; Gopalakrishnan, R. Growth and characterization of nonlinear optical single crystals: Bis(cyclohexylammonium) terephthalate and cyclohexylammonium para-methoxy benzoate. Bull. Mater. Sci. 2015, 38, 1291-1299. [CrossRef]

22. Yangui, A.; Garrot, D.; Lauret, J.-S.; Lusson, A.; Bouchez, G.; Deleporte, E.; Pillet, S.; Bendeif, E.-E.; Castro, M.; Triki, S. Optical investigation of broadband white-light emission in self-assembled organic-inorganic perovskite $\left(\mathrm{C}_{6} \mathrm{H}_{11} \mathrm{NH}_{3}\right)_{2} \mathrm{PbBr}_{4}$. J. Phys. Chem. C 2015, 119, 23638-23647. [CrossRef]

23. Zhao, W.; Jin, Y.; Zhang, W. Phase transitions in two organic salts based on 1,5-naphthalenedisulfonate. Sci. China Chem. 2016, 59, 114-121. [CrossRef]

24. Yangui, A.; Pillet, S.; Lusson, A.; Bendeif, E.-E.; Triki, S.; Abid, Y.; Boukheddaden, K. Control of the white-light emission in the mixed two-dimensional hybrid perovskites $\left(\mathrm{C}_{6} \mathrm{H}_{11} \mathrm{NH}_{3}\right)_{2}\left[\mathrm{PbBr}_{4-\mathrm{x}} \mathrm{I}_{\mathrm{x}}\right]$. J. Alloy. Compd. 2017, 699, 1122-1133. [CrossRef]

25. Yangui, A.; Pillet, S.; Bendeif, E.-E.; Lusson, A.; Triki, S.; Abid, Y.; Boukheddaden, K. Broadband emission in a new twodimensional Cd-based hybrid perovskite. ACS Photonics 2018, 5, 1599-1611. [CrossRef]

26. Bagabas, A.; Alsawalha, M.; Sohail, M.; Alhoshan, S.; Arasheed, R. Synthesis, crystal structure, and characterization of cyclohexylammonium tetraisothiocyanatocobaltate (II): A single-source precursor for cobalt sulfide and oxide nanostructures. Heliyon 2019, 5, e01139. [CrossRef]

27. Jones, P.; Sheldrick, G.; Kirby, A.; Abell, K. Bis(cyclohexylammonium) propargyl phosphate dihydrate, $2 \mathrm{C}_{6} \mathrm{H}_{14} \mathrm{~N}^{+} \cdot \mathrm{C}_{3} \mathrm{H}_{3} \mathrm{O}_{4} \mathrm{P}^{2-} \cdot 2 \mathrm{H}_{2} \mathrm{O}$. Acta Crystallogr. Sect. C Cryst. Struct. Commun. 1984, 40, 547-549. [CrossRef]

28. Gomathi, R.; Madeswaran, S.; Babu, D.R. Bulk growth, electrical, linear, third order nonlinear optical and optical limiting properties on bis(cyclohexylammonium) succinate succinic acid crystal. Mater. Chem. Phys. 2018, 207, 84-90. [CrossRef]

29. Dupont, N.; Barbey, C.; Pfund, E.; Lequeux, T.; Navaza, A. Crystal Structure of a Cyclohexylammonium Salt of the N-(2,2-Difluoro2-phosphonoethanethioyl) aspartate: A Difluorinated N-(Phosphonoacetyl)-L-aspartate (PALA) Thio Analogue. Anal. Sci. X-ray Struct. Anal. Online 2008, 24, x293-x294. [CrossRef]

30. Senthil, K.; Senthil, A.; Elangovan, K. Crystal structure, growth and physiochemical properties of nonlinear optical single crystal: Bis(cyclohexylammonium) dioxalate hydrate. J. Mol. Struct. 2020, 1209, 127926. [CrossRef]

31. Gomathi, R.; Ramasamy, G.; Vinitha, G.; Ramki, S.; Chen, S.M. Cyclohexylammonium Cinnamate Single Crystal for Nonlinear Optical Applications. J. Electron. Mater. 2020, 49, 3350-3356. [CrossRef]

32. Wang, J.-P.; Cheng, X.-X.; Wang, J.-G.; Chen, Q.-H. Cyclohexylammonium dichloroacetate. Acta Crystallogr. Sect. E Struct. Rep. Online 2005, 61, o4006-o4007. [CrossRef]

33. Cuquejo-Cid, A.; Garcia-Fernandez, A.; Garcia-Ben, J.; Senaris-Rodriguez, M.A.; Castro-Garcia, S.; Sanchez-Andujar, M.; VazquezGarcia, D. Photoluminescent and vapochromic properties of the Mn (II)-doped $\left(\mathrm{C}_{6} \mathrm{H}_{11} \mathrm{NH}_{3}\right) 2 \mathrm{PbBr}_{4}$ layered organic-inorganic hybrid perovskite. Polyhedron 2021, 193, 114840. [CrossRef]

34. Bagabas, A.A.; Alhoshan, S.B.; Ghabbour, H.A.; Kumar, C.; Fun, H.-K. Crystal structure of cyclohexylammonium thiocyanate. Acta Crystallogr. Sect. E Crystallogr. Commun. 2015, 71, o62-o63. [CrossRef]

35. Yun, S.-S.; Moon, H.-S.; Kim, C.-H.; Lee, S.-G. A novel, wave-like, two-dimensional anionic host with Cationic and neutral guests: Crystal structure of $\left[\mathrm{C}_{6} \mathrm{H}_{11} \mathrm{NH}_{3}\right]\left[\mathrm{Cu}_{2}(\mathrm{CN})_{3}\right] \cdot 2 \mathrm{C}_{6} \mathrm{H}_{5} \mathrm{NH}_{2}$. J. Coord. Chem. 2004, 57, 321-327. [CrossRef] 
36. Saminathan, K.; SethuSankar, K.; Muthamizhchelvan, C.; Sivakumar, K. Cyclohexylammonium picrate. Acta Crystallogr. Sect. E 2005, 61, o3605-o3607.

37. Kumara Swamy, K.; Said, M.A. Cyclohexylammonium 2'-hydroxy-2-biphenyl phosphonate. Acta Crystallogr. Sect. C Cryst. Struct. Commun. 2001, 57, 491-492. [CrossRef]

38. Bagabas, A.A.; Alsawalha, M.; Taha, K.K.; Albaid, A.; Sohail, M.; Alqahtani, M.; Alrasheed, R.; Alqarn, A.; Ashamari, B.; Parkin, I.P. High Surface Area of Polyhedral Chromia and Hexagonal Chromium Sulfide by the Thermolysis of Cyclohexylammonium Hexaisothiocyanatochromate (III) Sesquihydrate. Chem. Sel. 2021, 6, 4298-4311. [CrossRef]

39. Alshammari, A.; Mokhtar, M.; Arasheed, R.; Asayegh, A.; Bagabas, A. Acetone Reaction with Hydrogen over Mesoporous Magnesium Oxide-Supported Rhodium Nanoparticles. Top. Catal. 2019, 62, 795-804. [CrossRef]

40. Hogarth, G. Transition metal dithiocarbamates: 1978-2003. Prog. Inorg. Chem. 2005, 53, 71-561.

41. Coucouvanis, D. The chemistry of the dithioacid and 1,1-dithiolate complexes, 1968-1977. Prog. Inorg. Chem 1979, 26, 301-469.

42. Bond, A.; Martin, R. Electrochemistry and redox behaviour of transition metal dithiocarbamates. Coord. Chem. Rev. 1984, 54, 23-98. [CrossRef]

43. Heard, P.J. Main Group Dithiocarbamate Complexes. Prog. Inorg. Chem. 2005, 53, 1-69. [CrossRef]

44. Coucouvanis, D. The Chemistry of the Dithioacid and 1,1-Dithiolate Complexes. Prog. Inorg. Chem. 1970, 4, 233-371. [CrossRef]

45. Afzaal, M.; Malik, M.A.; O'Brien, P. Chemical routes to chalcogenide materials as thin films or particles with critical dimensions with the order of nanometres. J. Mater. Chem. 2010, 20, 4031-4040. [CrossRef]

46. Hollingsworth, N.; Roffey, A.; Islam, H.-U.; Mercy, M.; Roldan, A.; Bras, W.; Wolthers, M.; Catlow, C.R.A.; Sankar, G.; Hogarth, G. Active nature of primary amines during thermal decomposition of nickel dithiocarbamates to nickel sulfide nanoparticles. Chem. Mater. 2014, 26, 6281-6292. [CrossRef]

47. Baer, C.; Pike, J. Infrared spectroscopic analysis of linkage isomerism in metal-thiocyanate complexes. J. Chem. Educ. 2010, 87, 724-726. [CrossRef]

48. Forster, D.; Goodgame, D. Isothiocyanato complexes of nickel (II) and copper (II). Inorg. Chem. 1965, 4, 823-829. [CrossRef]

49. Cabeza, O.; Segade, L.; Domínguez-Pérez, M.; Rilo, E.; Ausín, D.; Seijas, J.A.; Vazquez-Tato, M.P.; Matleev, V.; Ievlev, A.; Salgado, J. Strange behaviour of transport properties in novel metal thiocyanate based ionic liquids. J. Mol. Liq. 2021, 340, 117164. [CrossRef]

50. Kauffman, G.B.; Beech, G. Thermal decomposition of solid isothiocyanate complexes: Part II. Kinetic parameters. Thermochim. Acta 1970, 1, 99-102. [CrossRef]

51. Abdu, B. Crystal Structure of Rubidium Nickel Thiocyanate Tetrahyderate $\mathrm{Rb}_{4} \mathrm{Ni}(\mathrm{SCN})_{6} \cdot 4 \mathrm{H}_{2} \mathrm{O}$. Int. J. Chem. Environ.Biol. Sci. (IJCEBS) 2016, 4, 12-15.

52. Forster, D.; Goodgame, D. Infrared Spectra (400-200 Cm.-1) of Some Thiocyanate and Isothiocyanate Complexes. Inorg. Chem. 1965, 4, 715-718. [CrossRef]

53. Vicente, R.; Escuer, A.; Solans, X.; Font-Bardía, M. Aqueous syntheses and crystal structures of the hexa- and pentacoordinated nickel(II) isothiocyanato derivatives of bulky triamines: $\left(\mathrm{H}_{2} \mathrm{Et}_{5} \text { dien }\right)_{2}\left[\mathrm{Ni}(\mathrm{NCS})_{6}\right],\left[\mathrm{Ni}\left(\mathrm{Me}{ }_{5} \mathrm{dien}\right)(\mathrm{NCS})_{2}\right]$ and [Ni(Me ${ }_{4}$ Etdien)(NCS) $)_{2}$. Inorg. Chim. Acta 1996, 248, 59-65. [CrossRef]

54. Petříček, V.; Dušek, M.; Palatinus, L. Crystallographic computing system JANA2006: General features. Z. Für Krist.-Cryst. Mater. 2014, 229, 345-352. [CrossRef]

55. Balachandran, V.; Murali, M.K. FT-IR and FT-Raman spectral analysis of 3-(trifluromethyl) phenyl isothiocyanate. Elixir Vib. Spec. 2011, 40, 5105-5107.

56. Silverstein, R.M.; Bassler, G.C. Spectrometric identification of organic compounds. J. Chem. Educ. 1962, 39, 546. [CrossRef]

57. Sundaraganesan, N.; Ayyappan, S.; Umamaheswari, H.; Joshua, B.D. FTIR, FT-Raman spectra and ab initio, DFT vibrational analysis of 2,4-dinitrophenylhydrazine. Spectrochim. Acta Part A Mol. Biomol. Spectrosc. 2007, 66, 17-27. [CrossRef]

58. Mani, P.; Umamaheswari, H.; Joshua, B.D.; Sundaraganesan, N. Molecular structure, vibrational spectra and NBO analysis of phenylisothiocyanate by density functional method. J. Mol. Struct. THEOCHEM 2008, 863, 44-49. [CrossRef]

59. Kauffman, K.L.; Culp, J.T.; Goodman, A.; Matranga, C. FT-IR study of $\mathrm{CO}_{2}$ adsorption in a dynamic copper (II) benzoatepyrazine host with $\mathrm{CO}_{2}-\mathrm{CO}_{2}$ interactions in the adsorbed state. J. Phys. Chem. C 2011, 115, 1857-1866. [CrossRef]

60. Lex, A.; Trimmel, G.; Kern, W.; Stelzer, F. Photosensitive polynorbornene containing the benzyl thiocyanate group-Synthesis and patterning. J. Mol. Catal. A Chem. 2006, 254, 174-179. [CrossRef]

61. Coenen, K.; Gallucci, F.; Mezari, B.; Hensen, E.; Van Sint Annaland, M. An in-situ IR study on the adsorption of $\mathrm{CO}_{2}$ and $\mathrm{H}_{2} \mathrm{O}$ on hydrotalcites. J. CO2 Util. 2018, 24, 228-239. [CrossRef]

62. Clark, R.; Goodwin, A. Infrared and laser Raman spectra of metal hexaisothiocyanate ions. Spectrochim. Acta Part A Mol. Spectrosc. 1970, 26, 323-330. [CrossRef]

63. Chamberlain, M.M.; Bailar, J.C., Jr. The infrared spectra of some thiocyanatocobalt ammines. J. Am. Chem. Soc. 1959, 81, 6412-6415. [CrossRef]

64. Groom, C.R.; Bruno, I.J.; Lightfoot, M.P.; Ward, S.C. The Cambridge Structural Database. Acta Crystallogr. Sect. B 2016, 72, 171-179. [CrossRef] [PubMed]

65. Wang, X.; Yu, L.; Hu, P.; Yuan, F. Synthesis of single-crystalline hollow octahedral NiO. Cryst. Growth Des. 2007, 7, $2415-2418$. [CrossRef] 
66. Motazedian, F.; Wu, Z.; Zhang, J.; Samsam Shariat, B.; Jiang, D.; Martyniuk, M.; Liu, Y.; Yang, H. Determining intrinsic stress and strain state of fibre-textured thin films by X-ray diffraction measurements using combined asymmetrical and Bragg-Brentano configurations. Mater. Des. 2019, 181, 108063. [CrossRef]

67. Karthikeyan, R.; Thangaraju, D.; Prakash, N.; Hayakawa, Y. Single-step synthesis and catalytic activity of structure-controlled nickel sulfide nanoparticles. Cryst. Eng. Comm. 2015, 17, 5431-5439. [CrossRef]

68. Elamin, N.; Modwi, A.; Aissa, M.B.; Taha, K.K.; Al-Duaij, O.K.; Yousef, T. Fabrication of Cr-ZnO photocatalyst by starch-assisted sol-gel method for photodegradation of congo red under visible light. J. Mater. Sci. Mater. Electron. 2021, 32, 2234-2248. [CrossRef]

69. Brandstetter, S.; Derlet, P.; Van Petegem, S.; Van Swygenhoven, H. Williamson-Hall anisotropy in nanocrystalline metals: X-ray diffraction experiments and atomistic simulations. Acta Mater. 2008, 56, 165-176. [CrossRef]

70. Mote, V.; Purushotham, Y.; Dole, B. Williamson-Hall analysis in estimation of lattice strain in nanometer-sized ZnO particles. J. Theor. Appl. Phys. 2012, 6, 1-8. [CrossRef]

71. Xia, H.; Xiahou, Y.; Zhang, P.; Ding, W.; Wang, D. Revitalizing the Frens method to synthesize uniform, quasi-spherical gold nanoparticles with deliberately regulated sizes from 2 to $330 \mathrm{~nm}$. Langmuir 2016, 32, 5870-5880. [CrossRef]

72. Vijaya, J.J.; Sekaran, G.; Bououdina, M. Effect of $\mathrm{Cu}^{2+}$ doping on structural, morphological, optical and magnetic properties of $\mathrm{MnFe}_{2} \mathrm{O}_{4}$ particles/sheets/flakes-like nanostructures. Ceram. Int. 2015, 41, 15-26. [CrossRef]

73. Rouquerol, J.; Rouquerol, F.; Llewellyn, P.; Maurin, G.; Sing, K.S. Adsorption by Powders and Porous Solids: Principles, Methodology and Applications; Academic Press: Cambridge, MA, USA, 2013.

74. Harraz, F.; Mohamed, R.; Shawky, A.; Ibrahim, I. Composition and phase control of Ni/NiO nanoparticles for photocatalytic degradation of EDTA. J. Alloy. Compd. 2010, 508, 133-140. [CrossRef]

75. Xing, W.; Li, F.; Yan, Z.-f.; Lu, G. Synthesis and electrochemical properties of mesoporous nickel oxide. J. Power Sources 2004, 134, 324-330. [CrossRef]

76. Juang, R.-S.; Wu, F.-C.; Tseng, R.-L. Characterization and use of activated carbons prepared from bagasses for liquid-phase adsorption. Colloids Surf. A Physicochem. Eng. Asp. 2002, 201, 191-199. [CrossRef]

77. Bruschi, L.; Mistura, G.; Nguyen, P.T.; Do, D.D.; Nicholson, D.; Park, S.-J.; Lee, W. Adsorption in alumina pores open at one and at both ends. Nanoscale 2015, 7, 2587-2596. [CrossRef] 